\title{
Differentiation of Paratischeria and Neotischeria gen. nov. (Lepidoptera, Tischeriidae), with a description of new, mostly Asteraceae-feeding species from Central and South America
}

\author{
Jonas R. Stonis ${ }^{1}$, \\ Arūnas Diškus, \\ Andrius Remeikis ${ }^{1}$, \\ Brigita Paulavičiūtè ${ }^{2}$, \\ Liliana Katinas ${ }^{3}$, \\ Nixon Cumbicus Torres ${ }^{4}$ \\ ${ }^{1}$ Institute of Ecology, \\ Nature Research Centre, \\ Akademijos St. 2, Vilnius 08412, Lithuania \\ ${ }^{2}$ Tadas Ivanauskas Zoological Museum, \\ Laisvès Ave. 106, Kaunas 44253, Lithuania \\ ${ }^{3}$ Museo de La Plata, \\ Paseo del Bosque s/n, \\ 1900 La Plata, Argentina \\ ${ }^{4}$ Department of Biological \\ and Agricultural Sciences, \\ Private Technical University of Loja, \\ San Cayetano s/n, Loja 1101608, Ecuador
}

We describe a new genus, Neotischeria Diškus \& Stonis, gen. nov., and four new species of trumpet moths. Three of them are trophically associated with Asteraceae plants: Neotischeria ochripennata Diškus \& Remeikis, sp. nov. and N. longa Diškus \& Stonis, sp. nov., discovered from the western part of the equatorial Andes, $N$. conexa Diškus \& Stonis, sp. nov., discovered from the eastern part of the central Andes, and N. poseidonia Diškus \& Stonis, sp. nov., discovered from Guatemala (the host plant is unknown; it is presumed to be a Malvaceae plant). We briefly discuss the diagnostics of Neotischeria gen. nov. by differentiating it from the most similar Paratischeria Diškus \& Stonis and Astrotischeria Puplesis \& Diškus. We also newly combine seven formerly Paratischeria species, including P. neotropicana Diškus \& Stonis, with Neotischeria and designate the latter species as the type species of a new genus. The new species are illustrated with photographs of the male and, if available, the female genitalia and the leaf mines. We also provide the first documentation of the hitherto little-known Peruvian Neotischeria capnota (Meyrick) deposited at NHMUK (London).

Keywords: host plants, leaf miners, leaf mines, new species, trumpet moths

\footnotetext{
* Corresponding author. Email: stonis.biotaxonomy@gmail.com
} 


\section{INTRODUCTION}

Tischeriidae, or trumpet moths, represent a relatively small family of leaf-mining lepidopterans. We expect over 300 species worldwide, but only about 175 Tischeriidae species have been documented so far. Many new species have already been collected and are ready for taxonomic description, but the majority are still awaiting discovery, particularly from the areas of South East Asia, equatorial Africa, and tropical America that are still poorly surveyed (Stonis, Solis, 2020). The adults of trumpet moths possess numerous specialised morphological characters, including long antennal sensillae trichodea on the male antenna, a modified phallus in the male genitalia, or ovipositor lobes covered with thickened peg-like setae along with unique, rod-like or plate-like projections known as prela in the female genitalia. The unique characters of Tischeriidae were overviewed in the monographs by Braun (1972) and Puplesis, Diškus (2003), as well as discussed and variously illustrated in recent papers, including those by Xu et al. $(2017,2018)$, Stonis et al. (2017, 2018a, 2019a, 2020a, 2020b, 2020c, 2021a, 2021b), and Stonis, Solis (2020).

Initially, the family comprised a single genus, Tischeria Zeller. However, before our study, Tischeridae was already comprised of six genera: Tischeria Zeller, 1839; Coptotriche Walsingham, 1890; Astrotischeria Puplesis \& Diškus, 2003; Paratischeria Diškus \& Stonis, 2017 (Stonis et al., 2017); Dishkeya Stonis, 2020 (Stonis, Solis, 2020), and Manitischeria Diškus \& Stonis, 2021 (Stonis et al., 2021b).

In the current paper, we briefly discuss the diagnostics of Paratischeria, which is characterised by a distinct dorsal sclerite in the male genitalia and the feeding of their larvae on Urticaceae, occasionally Malvaceae, host plants. Because of the absence of a dorsal sclerite, we exclude seven Asteraceae and Malvaceae-feeding species from Paratischeria and describe a new genus, Neotischeria Diškus \& Stonis, gen. nov.
We also describe four new Neotischeria species discovered from Guatemala (Central America) and the equatorial and central Andes (South America): N. conexa Diškus \& Stonis, sp. nov., $N$. ochripennata Diškus \& Remeikis, sp. nov., N. longa Diškus \& Stonis, sp. nov., and N. poseidonia Diškus \& Stonis, sp. nov. The host plant of the latter species remains unknown, and three other species are tropically associated with Liabum Adans and Smallanthus Mack. ex Small (Asteraceae).

Drawing upon our study of the lectotype and paralectotype of Neotischeria capnota (Meyrick, 1915) deposited at NHMUK, we provide the first documentation of this littleknown species.

\section{MATERIALS AND METHODS}

The documentation of taxa and description of the new species is based on the material deposited in the collections of the Zoological Institute of the Russian Academy of Sciences, St. Petersburg, Russia (ZIN); some male and female paratypes of Neotischeria conexa sp. nov. and $N$. longa sp. nov. are also deposited at the Nature Research Centre, Vilnius, Lithuania (NRC). Studies into the lectotype and paralectotype of $N$. capnota (Meyrick, 1915) are based on the material deposited at the Natural History Museum, London, United Kingdom (NHMUK).

Protocols regarding the study into Tischeriidae have been previously described: the collecting and rearing of leaf mines by Stonis et al. (2018a), and techniques of specimen dissection and genitalia mounts in Euparal by Stonis et al. (2014). The descriptive terminology, with a few exceptions, follows Puplesis, Diškus (2003).

The identifications of the Asteraceae host plants were undertaken by experts in the taxonomy of the family. Being based exclusively on field photographs (herbarium specimens were not collected and preserved) they should, therefore, be considered with caution. 
Permanent preparations on microscope slides were photographed and studied with a Leica DM2500 microscope and a Leica DFC420 digital camera. Adults were measured and studied using Lomo stereoscopic microscopes MBS-10 and photographed using a Leica S6D stereoscopic microscope with an attached Leica DFC290 digital camera.

For molecular analysis, genomic DNA was extracted from hind legs or whole adult specimen stored in $96 \%$ ethanol, using the GeneJet Genomic DNA Purification Kit (Thermo Fisher Scientific Baltics) following the manufacturer's specifications. PCR reactions were carried out in an Eppendorf Mastercycler gradient 5331 (Germany). Cycling parameters were an initial denaturation step at $94^{\circ} \mathrm{C}$ for $2 \mathrm{~min}$, followed by $94^{\circ} \mathrm{C}$ for $30 \mathrm{~s}, 50^{\circ} \mathrm{C}$ for $45 \mathrm{~s}$, and $72^{\circ} \mathrm{C}$ for $1 \mathrm{~min}$. This cycle was repeated 35 times, followed by $4 \mathrm{~min}$ of extension at $72^{\circ} \mathrm{C}$. PCR products were visualized on $1.5 \%$ agarose gel stained with ethidium bromide and UV light photographs of the gels with DNA bands were taken using 'Herolab' transluminator (Germany). The sequencing of some species was produced by the BigDye ${ }^{\circledast}$ Terminator v3.1 Cycle Sequencing Kit (Applied Biosystems) in Macrogen Inc. (Seoul, South Korea). The divergence was calculated using the Kimura two-parameter distance (Kimura, 1980) model and graphically displayed in a NeighbourJoining (NJ) tree by the MEGA 7 software (Kumar et al., 2016). The robustness of the inferred tree was evaluated by bootstrapping with 10,000 replicates; distantly related Pseudopostega bogotensis Vargas (Opostegidae) was used as an outgroup. Molecular methods used in this paper for a fragment of the NJ tree (Fig. 1) are described in more detail in Stonis et al. (2019b).

\section{DIFFERENTIATION OF PARATISCHERIA AND NEOTISCHERIA GEN. NOV.}

The genus Paratischeria Diškus \& Stonis was described for the species of specific morphology of the male genitalia (Stonis et al., 2017).
This genus differs from Astrotischeria Puplesis \& Diškus (described in Puplesis, Diškus, 2003) in the undivided, usually narrow valva (divided in Astrotischeria), long undivided uncus (usually short and divided in Astrotischeria), and the strongly, though variously, developed anellus (Stonis et al., 2017).

During current molecular studies into Tischeriidae species using fragments of the mitochondrial COI gene that included the standard barcode region and consequent studies on the obtained sequences of Paratischeria species, we found that there were two groups of the species which never clustered together in any of our phylogenetic trees but exhibited a clear dichotomy (Fig. 1).

The morphology of the male genitalia also differed significantly: the first group of the species possessed only a well-developed anellus (Figs 2-4), while the species of the second group were characterised by the presence of an anellus and a distinct dorsal sclerite, a unique, derived character within Tischeriidae (Figs 5-7). The feeding preferences also differed among the species of these two groups: the host plants of the first group belong to Asteraceae and Malvaceae, while the species of the second group feed on Urticaceae and occasionally on Malvaceae. By drawing on unpublished molecular data, the morphological characters that are easily applicable for further diagnostics, and differences in host-plant preferences, here we describe a new genus, $\mathrm{Ne}$ otischeria gen. nov.

Because of the absence of a dorsal sclerite in the male genitalia, we exclude seven Asteraceae- and Malvaceae-feeding species from former Paratischeria, and provide seven new taxonomic combinations with Neotischeria: N. guarani (Diškus \& Stonis, 2020) (comb. nov.), N. mesoamericana (Diškus \& Stonis, 2020) (comb. nov.), N. belizensis (Remeikis \& Stonis, 2020) (comb. nov.), N. robinsoni (Diškus \& Stonis, 2020) (comb. nov.), N. tubifex (Diškus \& Stonis, 2020) (comb. nov.), N. neotropicana (Diškus \& Stonis, 2015) (comb. nov.), and N. capnota (Meyrick, 1915) (comb. nov.). 


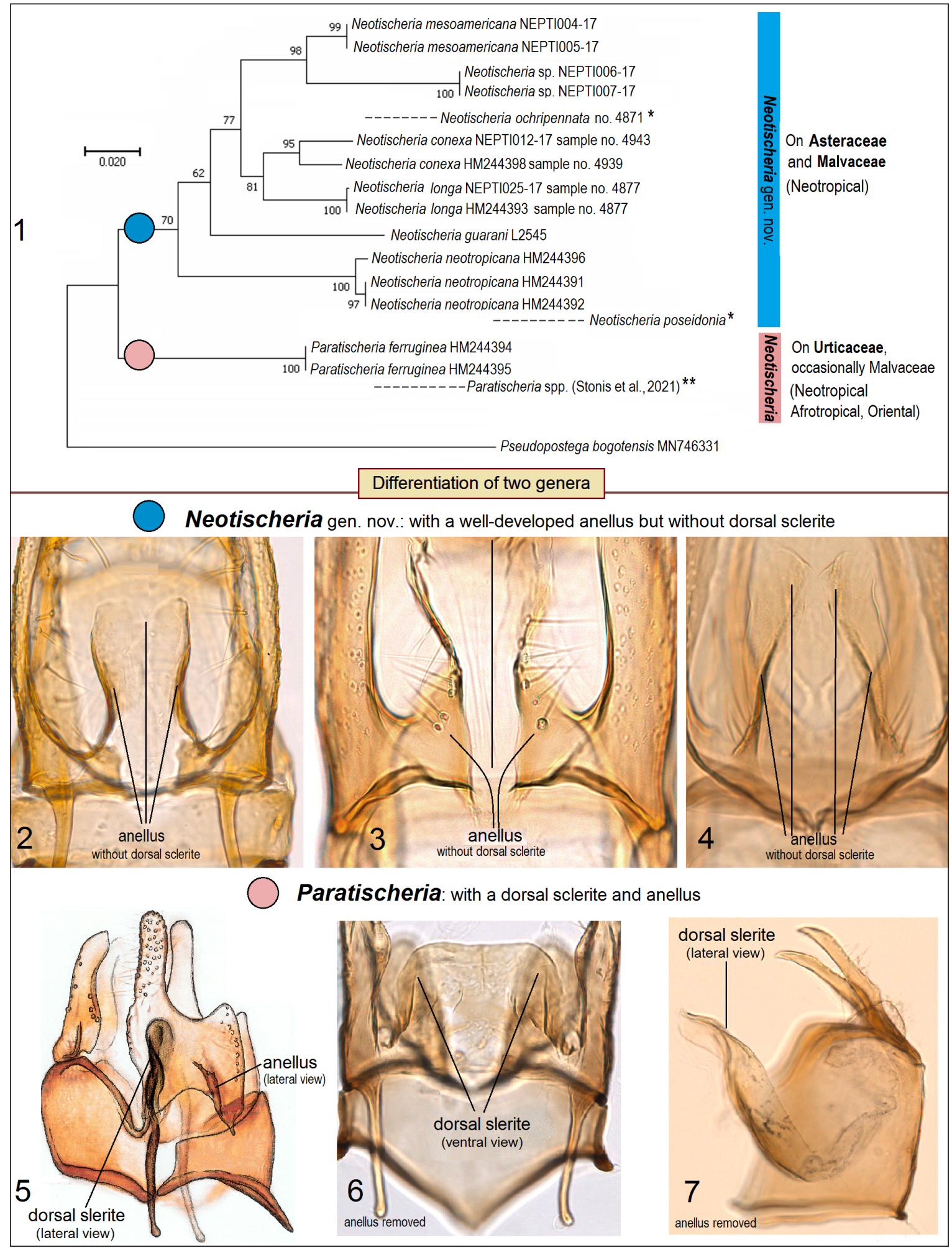

Figs 1-7. Differentiation of Neotischeria gen. nov. 1 - a fragment of Neighbour-Joining tree of Tischeriidae based on mtDNA COI sequences $\left(^{*}\right.$ - species exhibiting a striking morphological similarity with the species with the studied sequences; ${ }^{* *}$ - a group of species of those mtDNA COI sequences will be analysed separately, in another paper by Stonis et al., 2021a); 2-7 - differentiation of two related genera (2 - Neotischeria mesoamericana; 3 - N. guarani; 4 - N. poseidonia; 5 - Paratischeria ferruginea; 6 - same; 7 - P. boehmerica; Stonis et al., 2021a) 


\section{DESCRIPTION OF A NEW GENUS, WITH A REVIEW OF INCLUDED SPECIES}

\section{Neotischeria Diškus \& Stonis, gen. nov.}

urn:lsid:zoobank.org:act:14A682A5-F0B 14352-A828-4C4AA150123D

Type species. Neotischeria neotropicana (Diškus \& Stonis, 2015: 457-465).

Diagnosis. External characters or characters of wing venation are not informative or insufficient for generic differentiation in most cases of Tischeriidae, including this new genus. In the male genitalia, the combination of a slender, undivided, one-lobed valva, presence of a welldeveloped anellus, and the absence of a dorsal sclerite and transtilla distinguish the new genus from all other genera of Tischeriidae.

Description. Adult. Medium-small moths: forewing length $2.4-5.4 \mathrm{~mm}$, wingspan 5.4$11.3 \mathrm{~mm}$. Head: frons smoothly scaled; frontal tuft overlapping the frons, comprised of long lamellar scales; collar comprised of slender lamellar scales; antenna longer than one half the length of forewing. Male forewing without a distinctive pattern, from bright yellow-ochre to pale grey cream, irregularly speckled with some darker scales; females often exhibit a remarkable sexual dimorphism and are characterised of a bright, patchy forewing; fringe line usually present. Hindwing slender, from cream or pale ochreous brown to dark grey-brown, without androconia. Male abdomen with anal tufts.

Male genitalia. Capsule significantly longer than wide. Uncus with two long or very long latero-ventral lobes and with (or without) small, rounded, dorsal lobes. Socii membranous, not thickened. Valva usually slender, occasionally widened in basal part, always without dorsal lobes, undivided (one-lobed); basal process long; transtilla absent. Juxta absent. Anellus well-developed, thickened, and with some setae laterally. Vinculum with a large or medium large, distally usually rounded or triangular ventral lobe. Phallus slightly or broadly bifurcated apically, without spines or carinae, except for $N$. robinsoni Diškus \& Stonis and N. tubifex Diškus \& Stonis, and N. mesoamericana Diškus
\& Stonis (those species possess carina-like processes on the phallus).

Female genitalia with large or medium-large rounded ovipositor lobes densely clothed with short, modified peg-like setae. Anterior and posterior apophyses usually almost equal in length; prela comprised of three pairs of rodlike projections. Corpus bursae with long or very long and very slender caudal part, and relatively small and slender main part; without pectinations or signum. Accessory sac absent or inconspicous. Ductus spermathaecae very slender, with many large or often very large coils.

Bionomics. Host plants are mainly from the Asteraceae family, including Liabum Adans., Smallanthus Mack., Montanoa Cerv., Elephantopus L., Otopappus Benth., Lasianthaea DC., but in the case of the $N$. neotropicana group, some host plants are from Malvaceae (Sida spp.). Larvae mine leaves and produce blotch-like leaf mines, without distorting the mined leaf (i.e., without bending the leaf margin), except for $N$. neotropicana; the larva of the latter species distorts the mined leaf. Pupa in a circular, usually distinctive, nidus.

Distribution. Exclusively neotropical, endemic. Currently the genus is known from subtropical Mexico to Paraguay and the Yungas biogeographical province of Bolivia, with the majority of species in the tropical habitats of Central America (Belize and Guatemala), occurring at an elevation from just few metres above sea level to $3000-3100 \mathrm{~m}$ in the equatorial Andes of South America.

Etymology. The name Neotischeria (feminine) is a combination of the prefex neo (new), here derived from Neotropics where the genus is distributed, and the Latin name of another, iconic, type genus of the trumpet moth family, Tischeria.

Remarks. Unpublished molecular data provides support for this new genus. In our study, all sequences (with a final aligned length of the dataset 657 bp) have been deposited in the GenBank (www.ncbi.nlm.nih.gov/Genbank) and BOLD platform (www.barcodinglife.org); they will be published separately with a molecular analysis of all genera of Tischeriidae (Stonis et al., in prep.). 

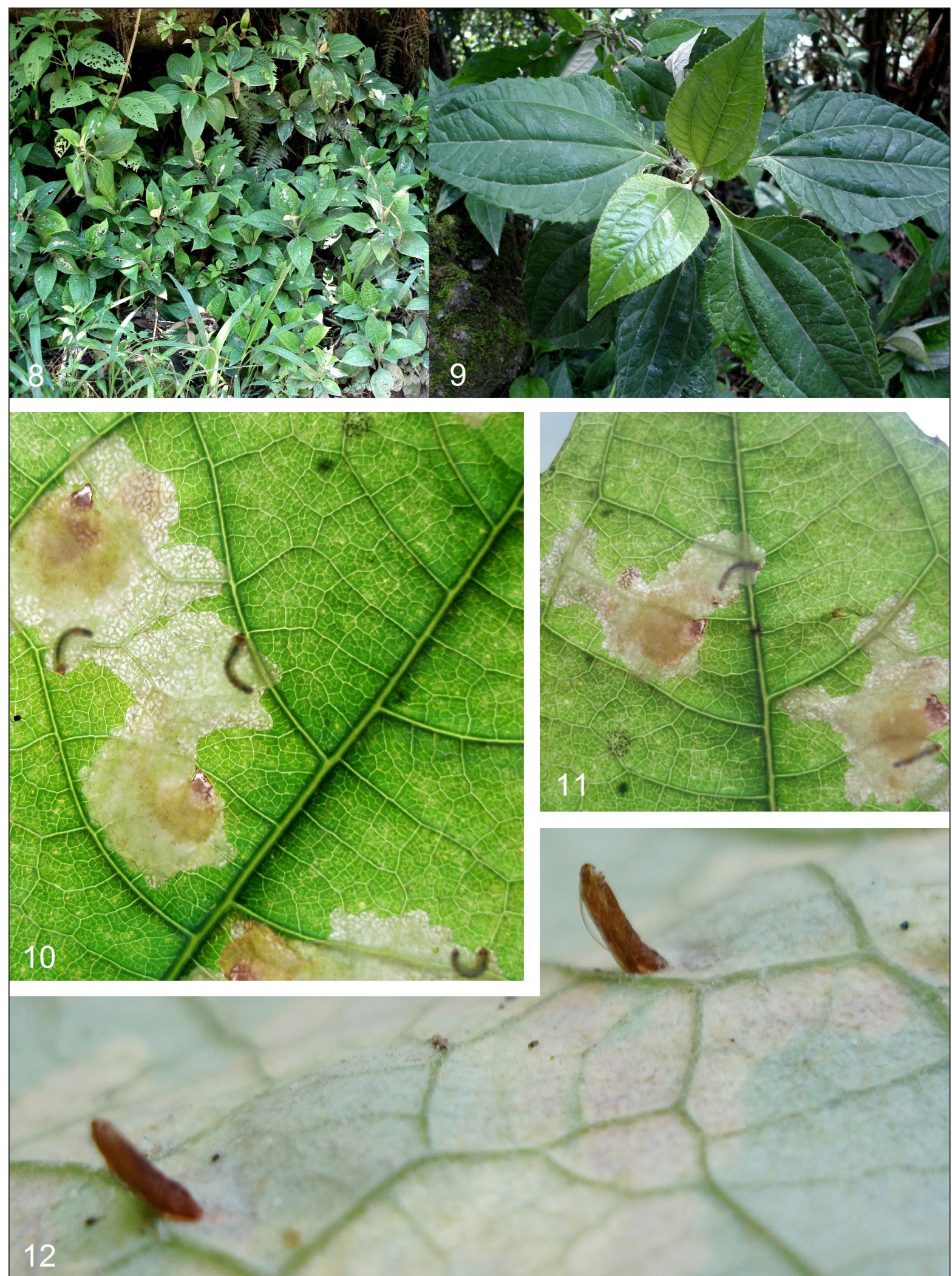

Figs 8-12. Bionomics of Neotischeria conexa Diškus \& Stonis, sp. nov., sample no. 4939 from Liabum vargasii H. Rob. (or L. solidagineum (Kunth) Less. 8, 9 - host plant; 10, 11 - leaf mines with feeding larvae; 12 - pupal exuviae 

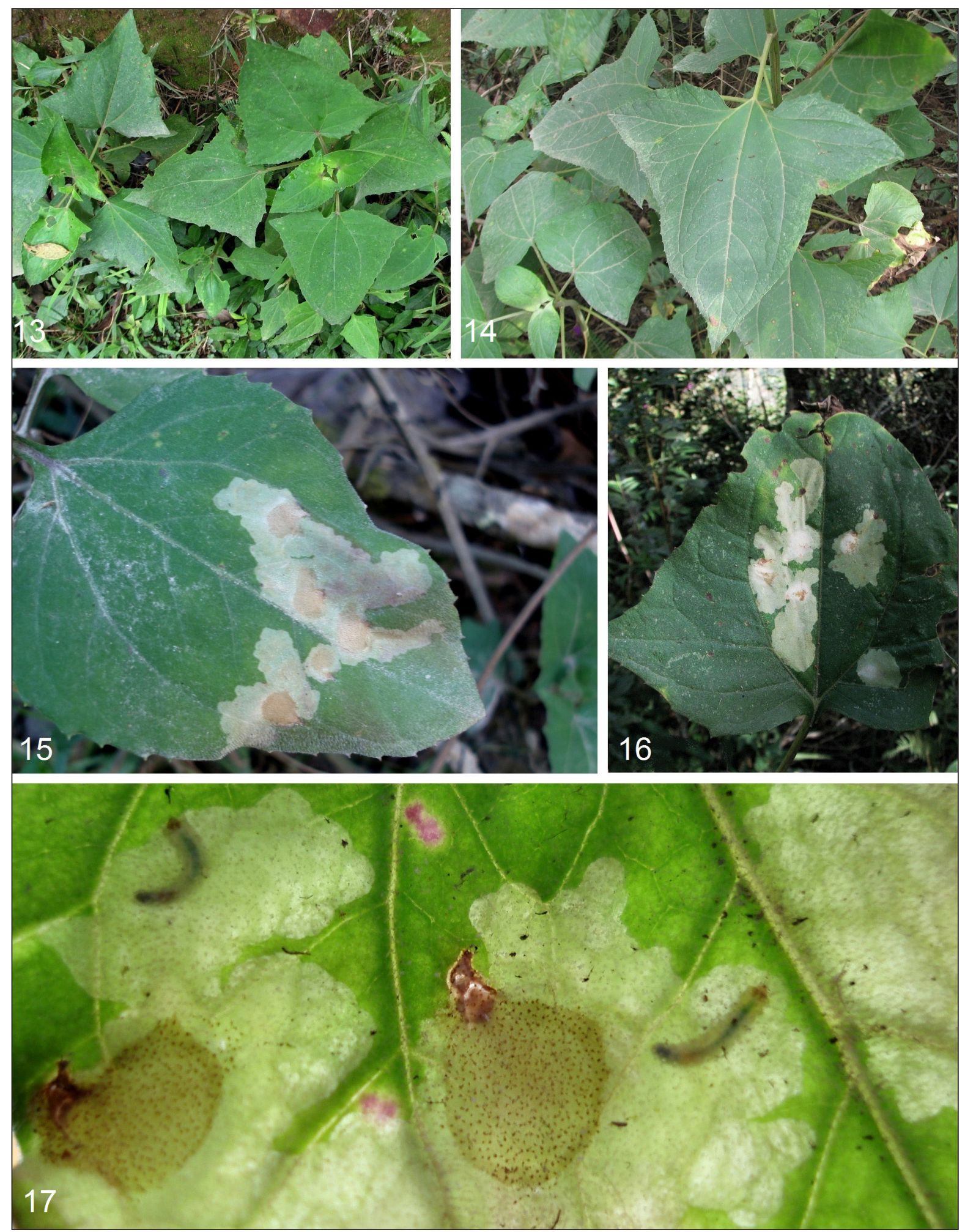

Figs 13-17. Bionomics of Neotischeria conexa Diškus \& Stonis, sp. nov.; 13, 14 - collecting sample no. 5239 from Liabum sp.; 15 - collecting sample on no. 4943 from Smallanthus sonchifolius (Poepp.) H. Rob.; 16 - collecting sample no. 5239, leaf mines; 17 - collecting sample no. 4943, feeding larvae and pale brown, circular nidus 

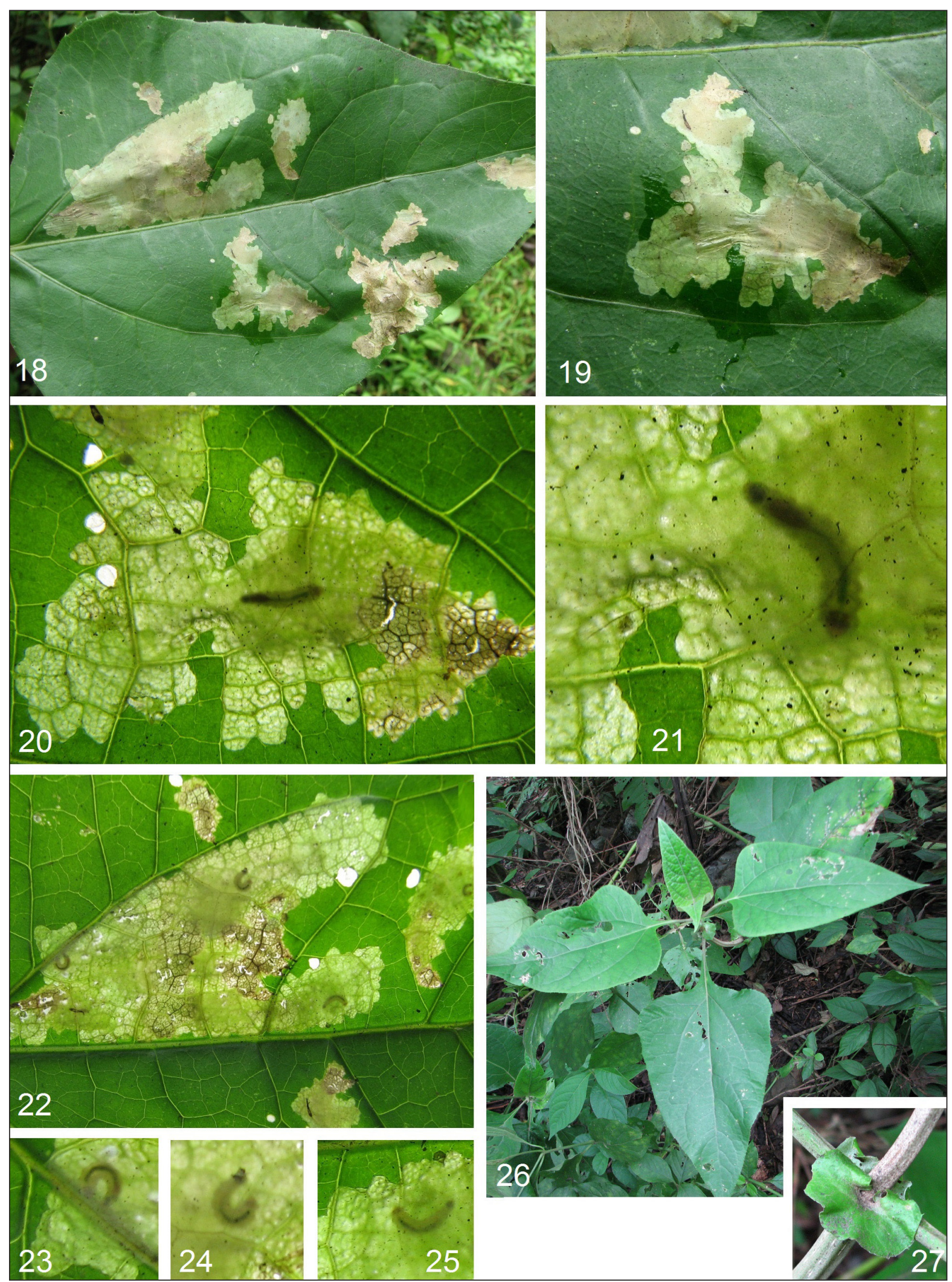

Figs 18-27. Bionomics of Neotischeria ochripennata Diškus \& Remeikis, sp. nov.; sample no. 4871 from Liabum floribundum Less. or L. stipulatum Rusby; 18-25 - leaf mines with feeding larvae; 26, 27 - host plant 

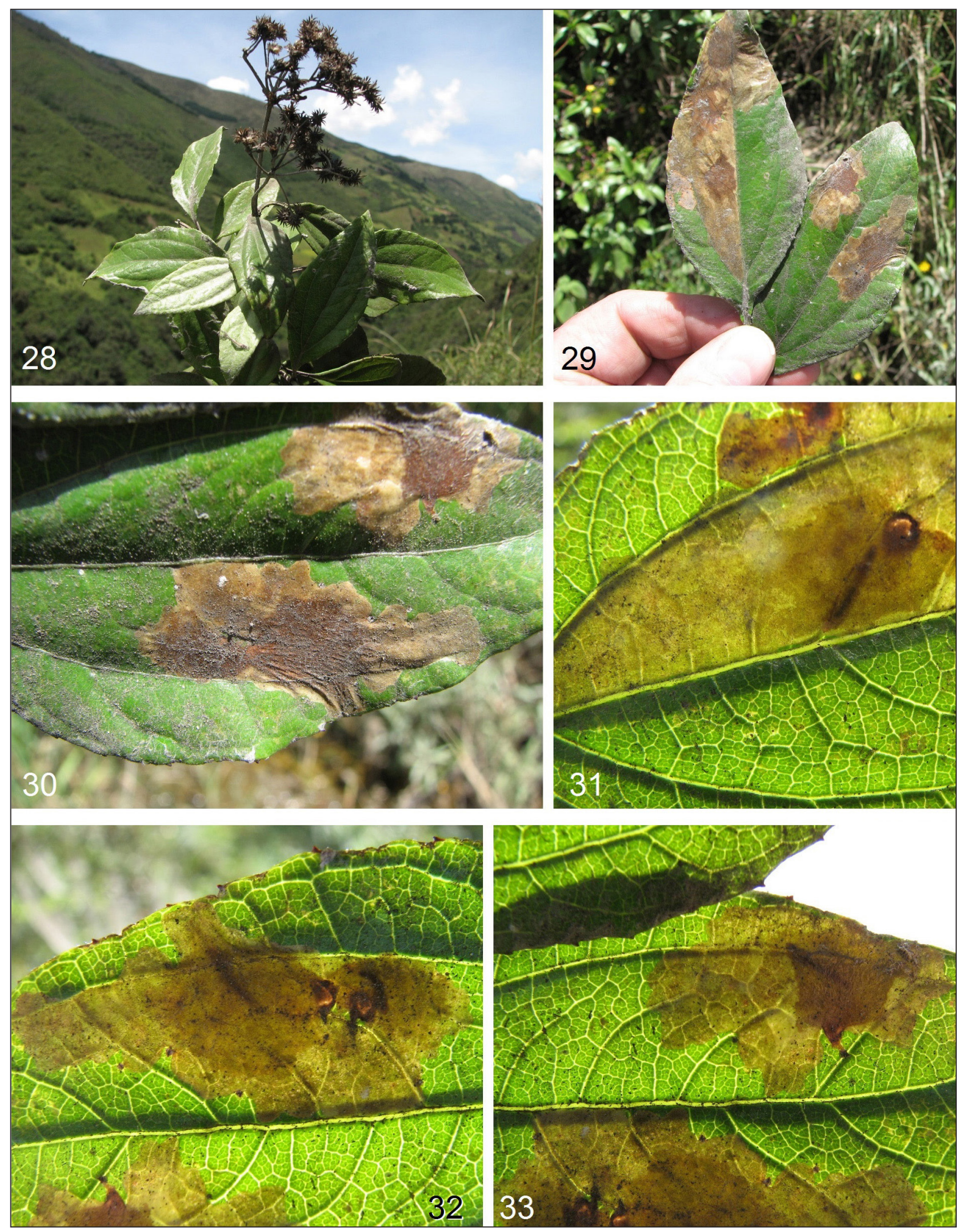

Figs 28-33. Bionomics of Neotischeria longa Diškus \& Stonis, sp. nov., sample no. 4877 from Liabum sp., possibly L. dillonii D. G. Gutiérrez \& Katinas or L. igniarium (Humb. \& Bonpl.) Less.; 28 - host plant; 29-33 - leaf mines 


\section{Neotischeria conexa Diškus \& Stonis, sp. nov.}

urn:lsid:zoobank.org:act:F5215674-D97A4952-AEF5-53CE4AFD983C

Type material. Holotype: $1 \hat{\delta}$, BOLIVIA, Nor Yungas Province, Coroico, 16 $16^{\circ} 26^{\prime \prime}$, $67^{\circ} 43^{\prime} 54^{\prime \prime} \mathrm{W}$, elevation ca. $1650 \mathrm{~m}$, mining larva on Liabum sp., Asteraceae, 7-12.vi.2018, ex pupa vi.-vii.2018, field card no. 5239, leg. A. Diškus, J. R. Stonis, genitalia slide no. AD1085 (ZIN). Paratypes (16 $\hat{\delta}, 18$ †): $6 \hat{\sigma}, 7$, BOLIVIA, same label data as holotype, genitalia slide no. AD1084ㅇ (ZIN). Paratypes: $1 \hat{\partial}, 1$, samelabel data as holotype (NRC); 4, 6, , PERU, Urubamba Province, near Machu Picchu, 139'35”S, $72^{\circ} 31^{\prime} 58^{\prime \prime} \mathrm{W}$, elevation ca. $2010 \mathrm{~m}$, mining larvae on Liabum sp., Asteraceae, 19.x.2008, ex pupa xi.2008, field card no. 4939, leg. A. Diškus, genitalia slides nos. $\mathrm{AD} 842 \hat{\gamma}, \mathrm{AD} 1080 \hat{\jmath}, \mathrm{AD} 886$ 우, $\mathrm{AD} 1081$ 우 (ZIN); 5 đิ, 3 ㅇ, PERU, Urubamba Province, near Machu Picchu, 13 $9^{\circ} 44^{\prime \prime}$, $72^{\circ} 32^{\prime 2} 29^{\prime \prime} \mathrm{W}$, elevation ca. $2190 \mathrm{~m}$, mining larvae on Smallanthus sp., 19.x.2008, ex pupa xi.2008, field card no. 4943, leg. A. Diškus, genitalia slides nos $\mathrm{AD} 844 \hat{\jmath}, \mathrm{AD} 1078 \hat{\circ}, \mathrm{AD} 1079$ 우 (ZIN); 1 q same label data (NRC).

Diagnosis. From the most similar Neotischeria longa sp. nov. and N. ochripennata sp. nov. (described below) it differs in the smaller size of the adults and male genitalia. Additionally, from $N$. longa sp. nov. it differs in the white leaf mines (dark brown in N. longa); from N. ochripennata it differs in the blackish brown darkenings on male forewing (forewing ochre-yellow in N. ochripennata) and the slender phallus (basally widened in N. ochripennata).

Male (Figs 34-36). Forewing length 3.3$3.9 \mathrm{~mm}$; wingspan $7.6-8.4 \mathrm{~mm}(n=14)$.

Head. Frons, palpi, and pectens ochreous cream; frontal tuft and collar comprised of brownish grey, cream-tipped lamellar scales; sometimes collar grey-black; antenna significantly longer than one half the length of forewing; flagellum dark grey-brown, with the first antennal segment ochreous yellow; at certain angle of view, flagellum ochre cream basally; sensilla rather long, distinctive.
Thorax. Tegula densely covered with greybrown, cream-tipped scales or entirely dark grey-black. Thorax glossy, pale brownish grey to dark grey. Forewing dark yellow-ochre, densely speckled with grey-brown or blackish grey brown scales along the costal margin and apically; fringe grey to dark grey, without a fringe line; forewing underside dark brown-grey to black-grey, with small scaleless spots and greyblack special scales along costa basally. No androconia. Hindwing grey to dark grey on upper side and underside, without androconia; fringe grey. Legs pale yellow-ochre, dark brown-grey to black-grey on the upper side.

Abdomen. Glossy, black-grey or grey, sometimes with some purple iridescence on upper side; paler, glossy grey, usually with some ochre scales on underside; anal tufts dorsal, long, dark grey but not always distinctive; genital segments dark grey to grey. Genitalia (Figs 50, 55-59) with capsule 420-430 $\mu \mathrm{m}$ long (or 435$500 \mu \mathrm{m}$ long if measured from vinculum to valval tips), $225-250 \mu \mathrm{m}$ wide. Uncus (Figs 50, 58) comprised of two long latero-ventral lobes and two short rounded dorsal lobes (Fig. 56). Valva (Figs 55, 58) 300-350 $\mu \mathrm{m}$ long (excluding the basal process), undivided, slender, basally fussed with anellus (Figs 50, 55). Anellus (Fig. 55) strongly thickened laterally, with two long, membranous lobes caudally. Vinculum triangular (Figs 50, 55, 57). Phallus about $375 \mu \mathrm{m}$ long, slender, apically divided, without lobes or spines (Figs 57, 59).

Female (Figs 38-42). Forewing length 2.9$4.0 \mathrm{~mm}$; wingspan 6.5-8.7 $\mathrm{mm}(n=13)$.

Head. Similar to male but tends to be darker.

Thorax. Usually darker than in male. Forewing with large, irregular, ochre spots.

Abdomen. Genitalia (Figs 53, 54, 81-86) about $1465 \mu \mathrm{m}$ long. Ovipositor lobes (Fig. 85) relatively large, rounded, densely clothed with peg-like setae; area between ovipositor lobes relatively wide, with tiny papillae usually collected in two rows (Fig. 53). Second pair of lobes, lateral and anterior to the ovipositor lobes, twice smaller than ovipositor lobes and bearing very long slender lamellar and piliform setae. Anterior and posterior apophyses almost 
equal in length; prela comprised of three pairs of rod-like projections (Fig. 86). Corpus bursae (Fig. 81) relatively short, basally oval-shaped, without pectinations or signum. Accessory sac absent or indistinctive. Ductus spermathecae very slender, with about $8-10$ very large coils (Figs 82, 83).

Bionomics (Figs 8-17). Host plants (Figs 8, 9, 13, 14) are Asteraceae plants: Liabum spp. (Figs 8, 9, 13, 14), including L. vargasii $\mathrm{H}$. Rob.

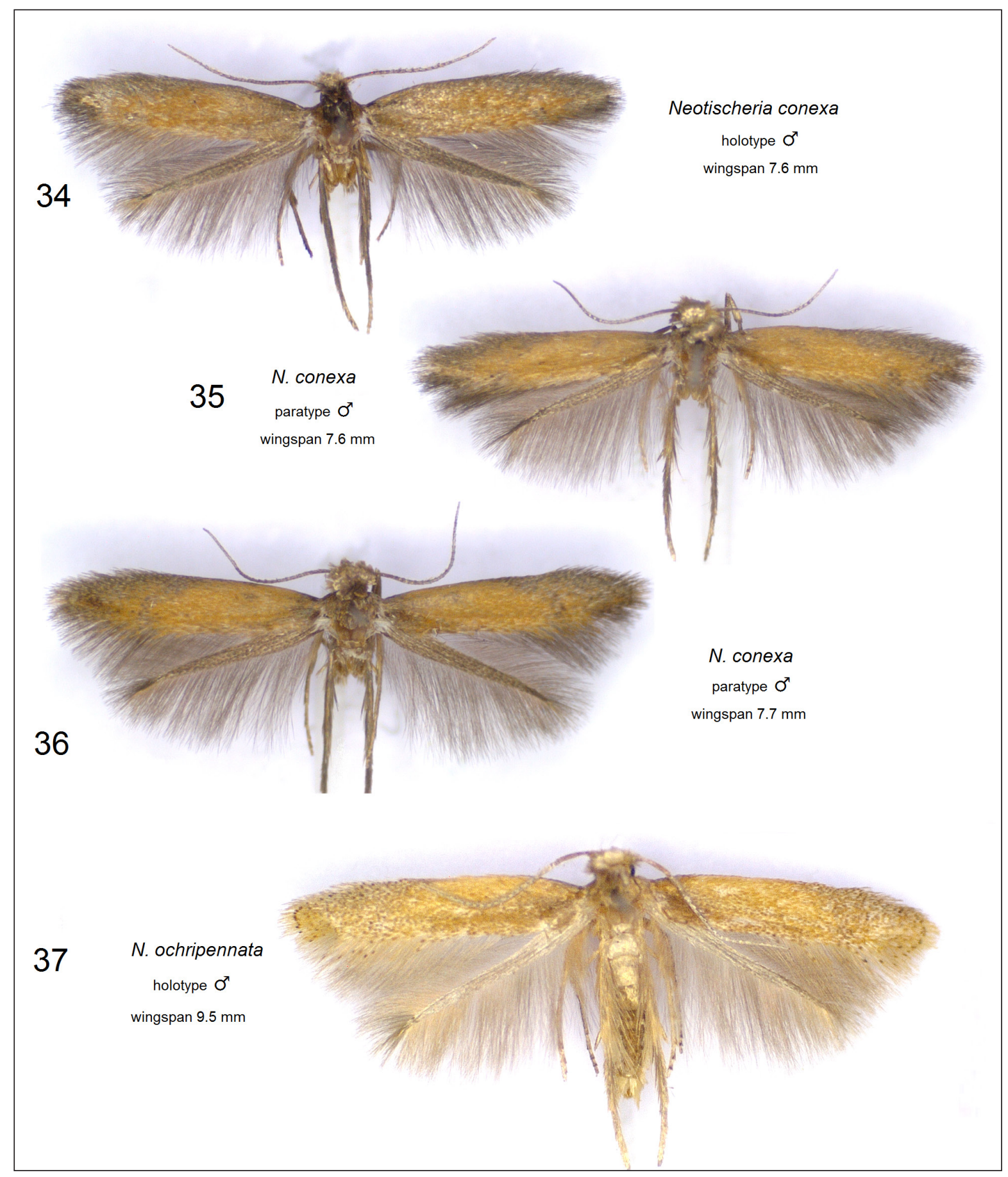

Figs 34-37. Male adults of new Neotischeria species. 34 - N. conexa Diškus \& Stonis, sp. nov., holotype, sample no. 5239; 35 - same, paratype, sample no. 4943; 36 - same, paratype, sample no. 4939; 37 - N. ochripennata Diškus \& Remeikis, sp. nov., holotype, sample no. 4871 


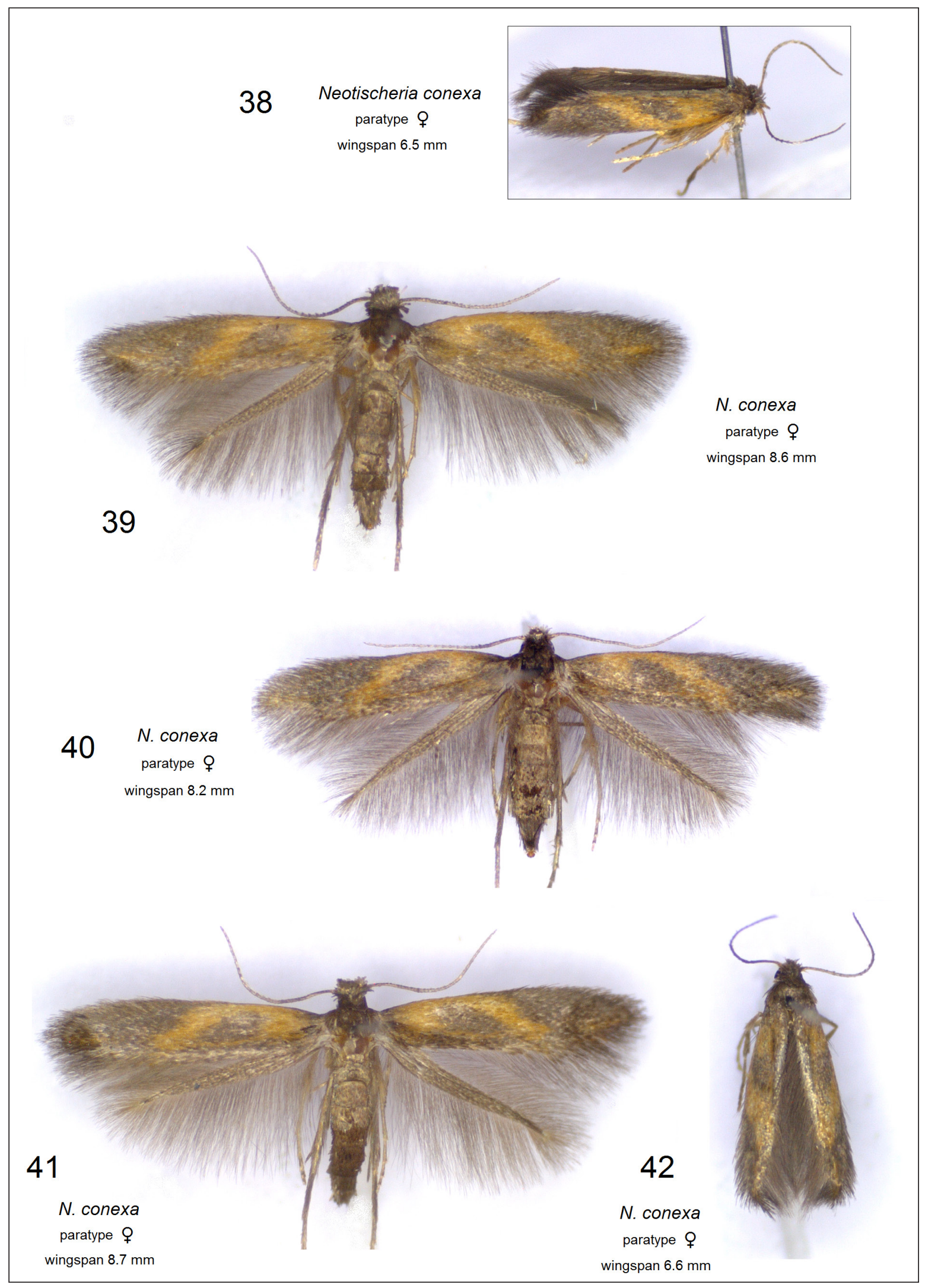

Figs 38-42. Female adults of Neotischeria conexa Diškus \& Stonis, sp. nov., paratypes. 38 - sample no. 5239; 39 - sample no. 4939; 40 - sample no. 5239; 41 - sample no. 4943; 42 - sample no. 5239 


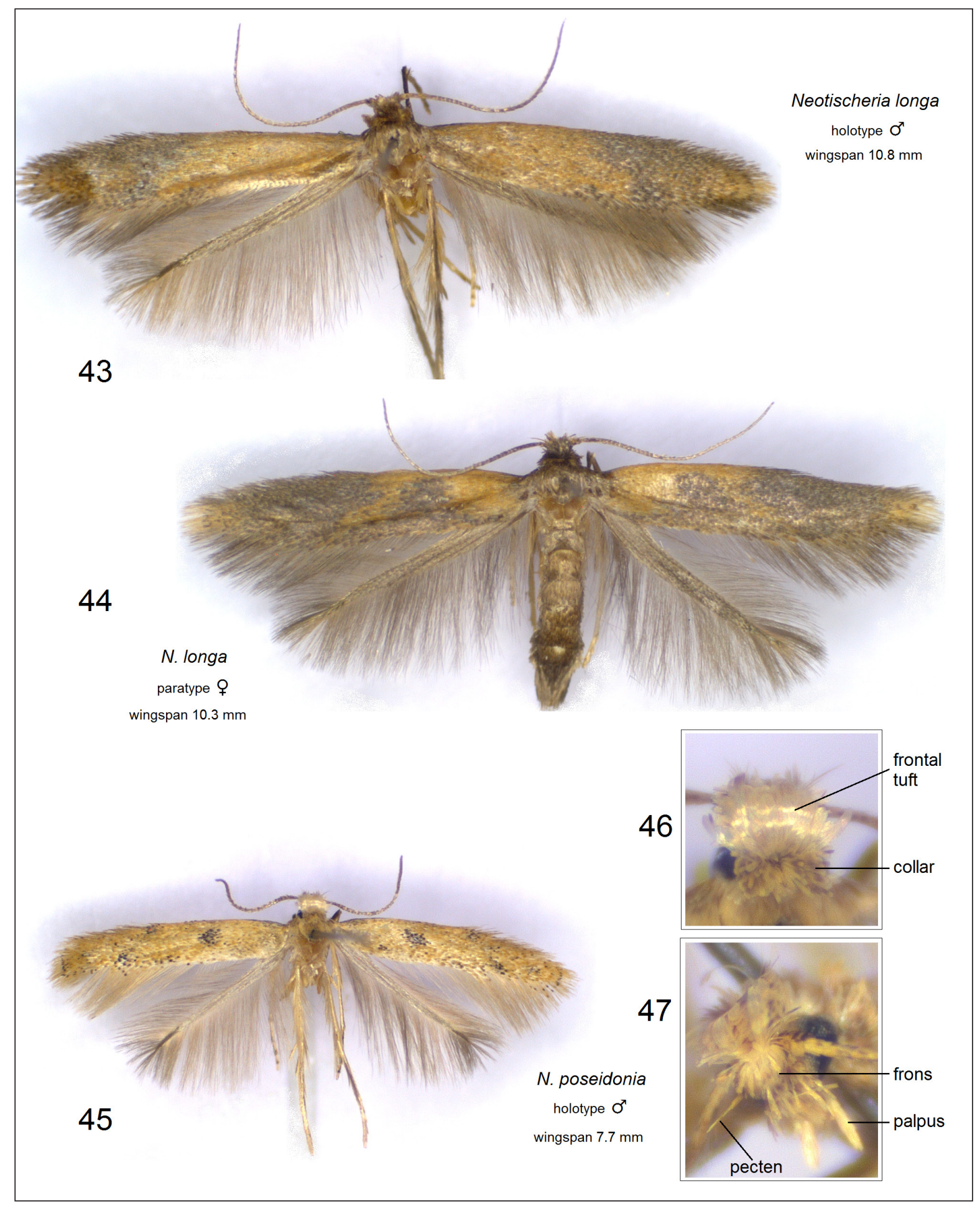

Figs 43-47. Adults of new Neotischeria species. 43 - N. longa Diškus \& Stonis, sp. nov., male holotype; 44 - same, female paratype; 45 - N. poseidonia Diškus \& Stonis, sp. nov., holotype, host plant unknown; 46, 47 - same, details of head

or L. solidagineum (Kunth) Less. and Smallanthus sonchifolius (Poepp.) H. Rob. (Fig. 15). Larvae mine in leaves in June and October and produce blotch-like leaf mines (Figs 10, 11, 15-17). Pupation in a circular distinctive nidus inside the leaf mine (Figs 10, 15, 17); colour of 
the nidus varies from transparent white to pale brown. Adults fly in late June-July and November. Otherwise, the biology is unknown.

Distribution. The species is known from the tropical or subtropical habitats in the eastern part of the Peruvian and Bolivian Andes, at an elevation of about $1600-2200 \mathrm{~m}$.

Etymology. The species name is derived from the Latin conexa (combined), in reference to the combined rearing samples from different host plants.

\section{Neotischeria ochripennata Diškus \& Re- meikis, sp. nov.}

urn:1sid:zoobank.org:act:3929E91F-D1904613-A9FC-9ECDBFB832DA

Type material. Holotype: $1 \lambda$, ECUADOR: Chimborazo Province, $15 \mathrm{~km}$ NE Bucay (Cumanda), 2 ${ }^{\circ} 11^{\prime} 5^{\prime \prime}$ ', $79^{\circ} 4^{\prime} 14^{\prime \prime} \mathrm{W}$, elevation ca. $810 \mathrm{~m}$, mining larva on Liabum sp., Asteraceae, 18.ii.2007, field card no. 4871, leg. A. Diškus,

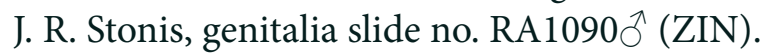
Paratypes $(2 \hat{\delta}): 1 \hat{\jmath}$, same label data as holotype, genitalia slide no. AD1086 $(\mathrm{ZIN}) ; 1$ त, ECUADOR: Pichincha Province, $31 \mathrm{~km}$ NW Alóag, $0^{\circ} 26^{\prime} 37^{\prime \prime}$ S, 78² $42^{\prime} 57^{\prime \prime} \mathrm{W}$, elevation ca. $2220 \mathrm{~m}$, from feeding larva, 25.ii.2007, field card no. 4898, leg. A. Diškus, J. R. Stonis, genitalia slide no. AD1089 $\widehat{\jmath}$ (ZIN) (also see Remarks).

Diagnosis. From the most similar $\mathrm{Ne}$ otischeria conexa sp. nov. and $N$. longa sp. nov. (described in the current paper) it differs in the bright ochre-yellow male forewing and fringe (fringe grey and forewing densely speckled with dark scales in N. conexa and N. longa). In the male genitalia, $N$. ochripennata sp. nov. differs in the distinctive, clearly visible basal extensions of the valva (Figs 49, 62, 67). Additionally, $N$. ochripennata differs from $N$. longa in the white leaf mines (dark brown in N. longa).

Male (Fig. 37). Forewing length 3.8-4.2 mm; wingspan 8.5-9.5 $\mathrm{mm}(\mathrm{n}=2)$.

Head. Frons, palpi, and pectens ochre cream to pale ochre-yellow; frontal tuft and collar glossy, comprised of golden cream or pale ochre-yellow lamellar scales; antenna slightly longer than one half the length of forewing; flagellum pale yellowish grey, basally ochre-yellow; sensilla whitish cream, rather distinctive but very fine.

Thorax. Tegula covered with ochre-brown, cream-tipped scales, distally cream. Thorax ochre cream, speckled with some ochre-brown scales. Forewing bright ochre-yellow, sparsely speckled with some pale brown scales in apical third; fringe bright ochre-yellow to pale ochre-yellow, with a fringe line of brown-black scales; forewing underside dark ochre-brown, with small scaleless spots and brown-black special scales along costa basally. No androconia. Hindwing grey to pale grey-brown on upper side, pale grey on underside, without androconia; fringe pale grey, ochre glossy. Legs ochreyellow on underside, dark grey-brown on upper side, with or without some purple iridescence.

Abdomen. Golden ochreous yellow, densely speckled with dark ochre-brown scales on upper side and underside; anal tufts lateral and dorsal (the latter longer), pale ochreous yellow; genital segments golden glossy, ochreous cream. Genitalia (Figs 49, 60-67) with capsule about $490 \mu \mathrm{m}$ long (or $570 \mu \mathrm{m}$ long if measured from vinculum to valval tips), $245-250 \mu \mathrm{m}$ wide. Uncus comprised of two long lateroventral lobes (Fig. 60) and two short, rounded dorsal lobes (Fig. 61). Valva (Figs 62, 66) about $390 \mu \mathrm{m}$ long (excluding the basal process), undivided, slender, basally fussed with anellus (Fig. 66) and with a distinctive basal extension (Figs 62, 67). Anellus (Fig. 63) long, strongly thickened laterally, with two long, membranous lobes caudally. Vinculum triangular distally (Figs 66, 67). Phallus about $450 \mu \mathrm{m}$ long, basally widened (Fig. 67), apically divided, without spines (Figs 62-67).

Female. Unknown (see Remarks).

Bionomics (Figs 18-27). Host plant is $L i$ abum floribundum Less. (or L. stipulatum Rusby), Asteraceae (Figs 26, 27). Larvae mine in leaves in February and produce blotch-like leaf mines (Figs 18-25). Pupation in a circular nidus inside the leaf mine (Fig. 20); the nidus is transparent, rather indistinctive. Adults fly in March. Otherwise, the biology is unknown. 


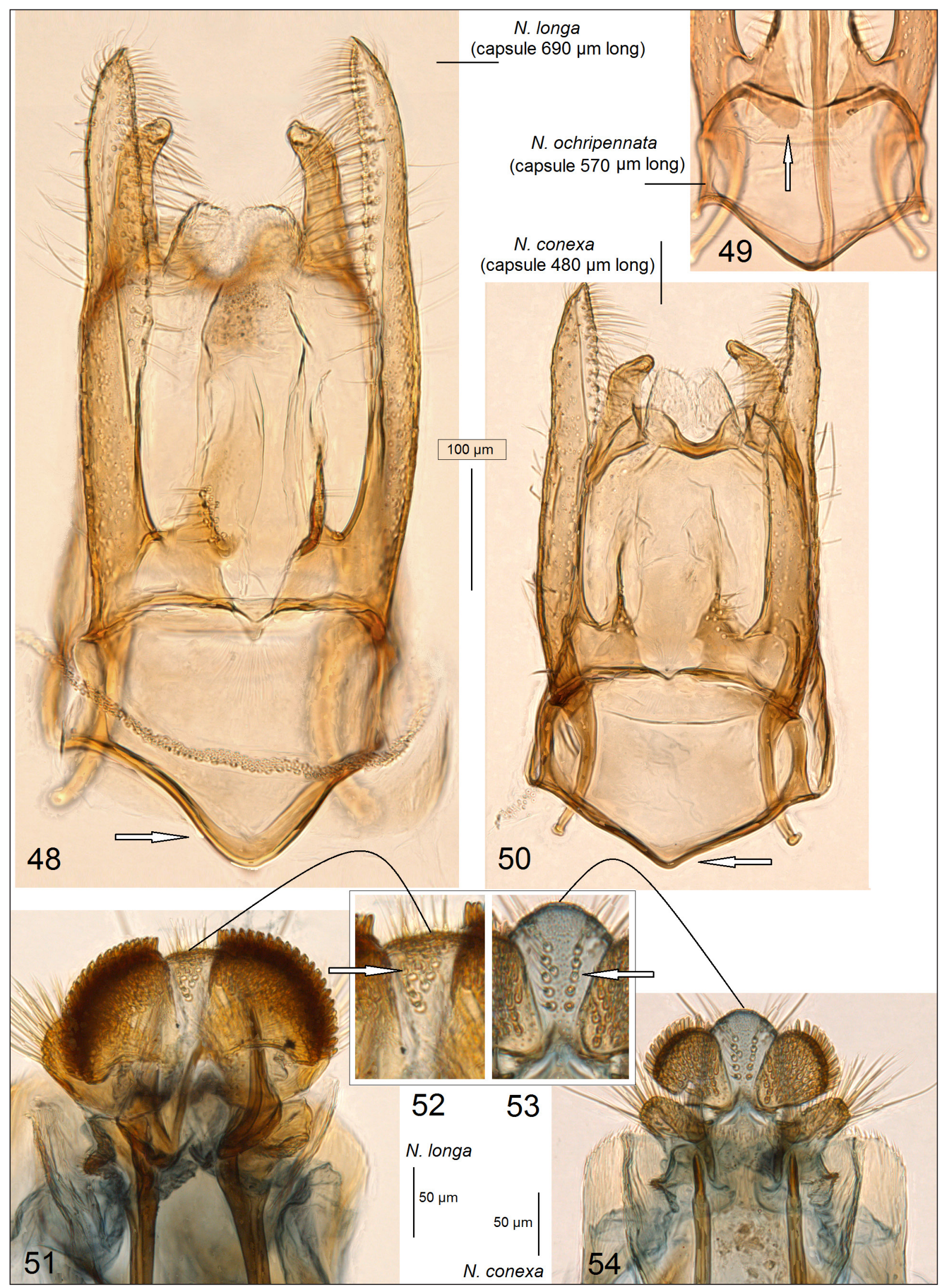

Figs 48-54. Differentiation of related Neotischeria species. 48 - N. longa Diškus \& Stonis, sp. nov., male genitalia with phallus removed; 49 - same, N. ochripennata Diškus \& Remeikis, sp. nov.; 50 - same, N. conexa; 51,52 - details of female genitalia, ovipositor lobes, N. longa; 53, 54 - same, N. conexa 


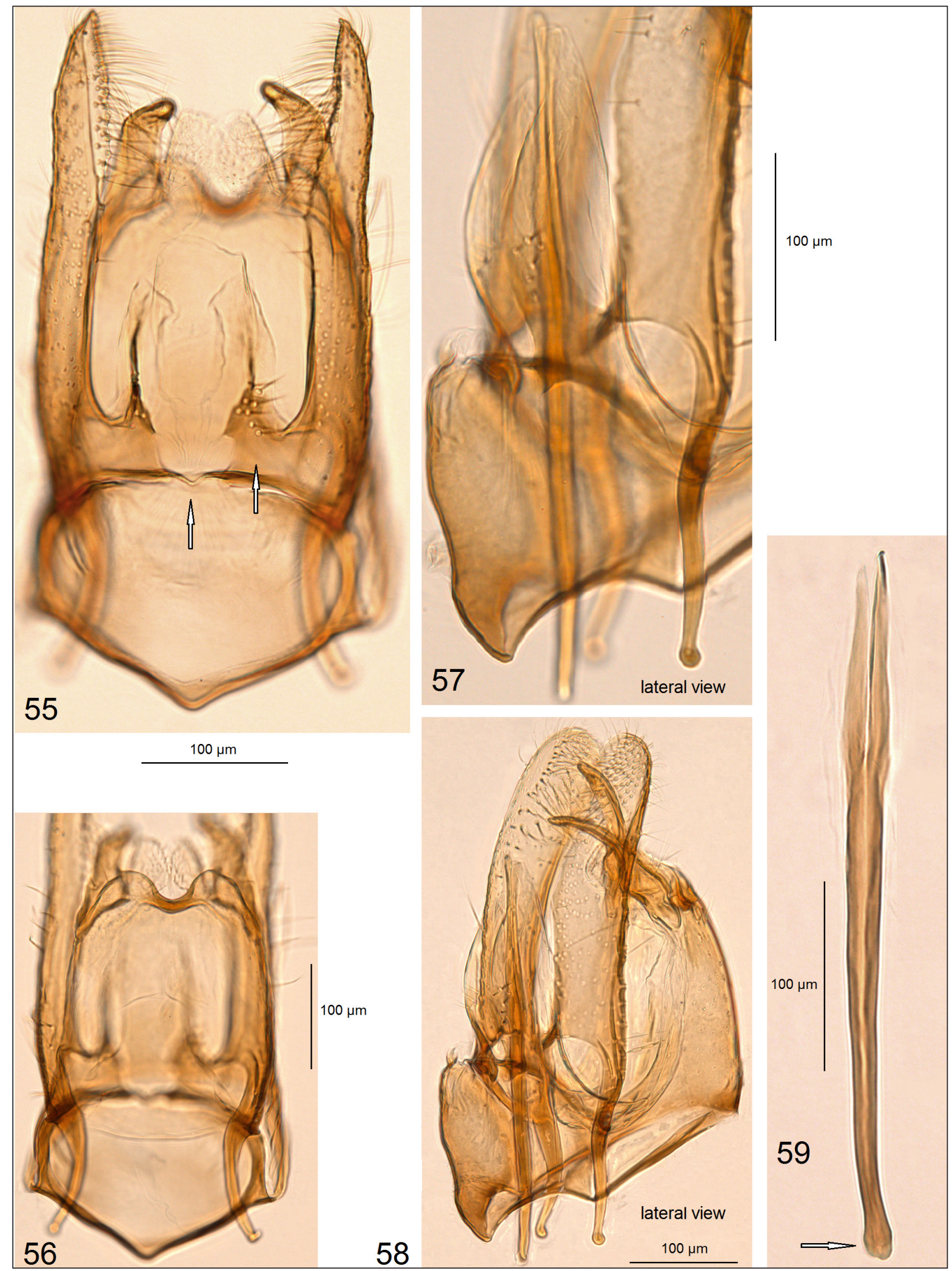

Figs 55-59. Male genitalia of Neotischeria conexa Diškus \& Stonis, sp. nov.; 55, 56 - capsule with phallus removed, holotype, genitalia slide no. AD1085 (ZIN); 57, 58 - capsule with phallus inside, lateral view, paratype, genitalia slide no. AD844 (ZIN); 59 - phallus, holotype, genitalia slide no. AD1085 (ZIN) 


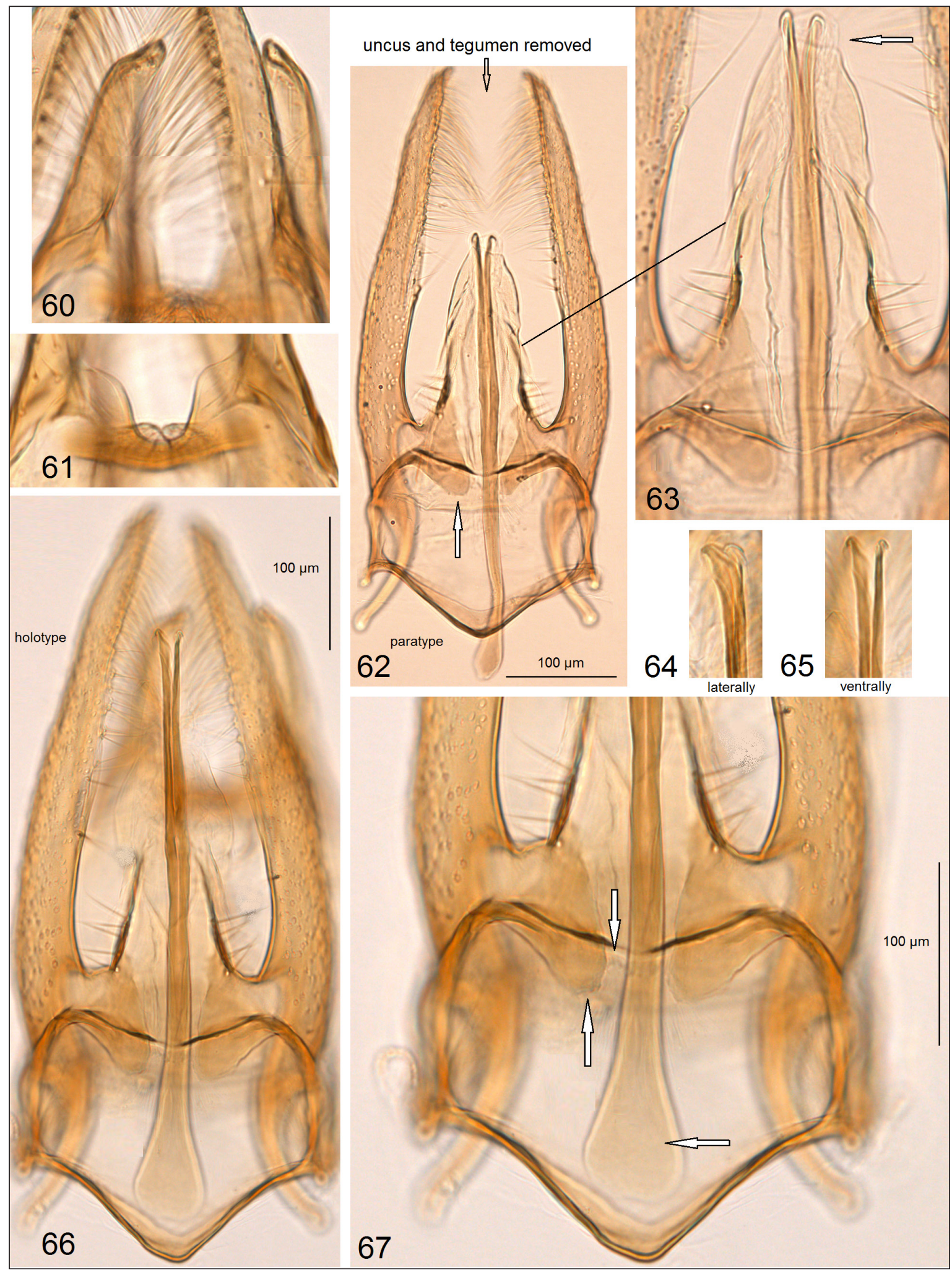

Figs 60-67. Male genitalia of Neotischeria ochripennata Diškus \& Remeikis, sp. nov.; 60 - holotype, slide no. RA1090, uncus, dorsal lobes; 61 - same, ventral lobes; 62, 63 - paratype, slide no. AD1086, capsule with uncus and tegumen removed; 64 - apex of phallus, lateral view, temporary slide no. RA1090; 65 - same, ventral view, permanent slide no. RA1086; 66, 67 - capsule with phallus inside, lateral view, holotype, slide no. RA1090 (ZIN) 


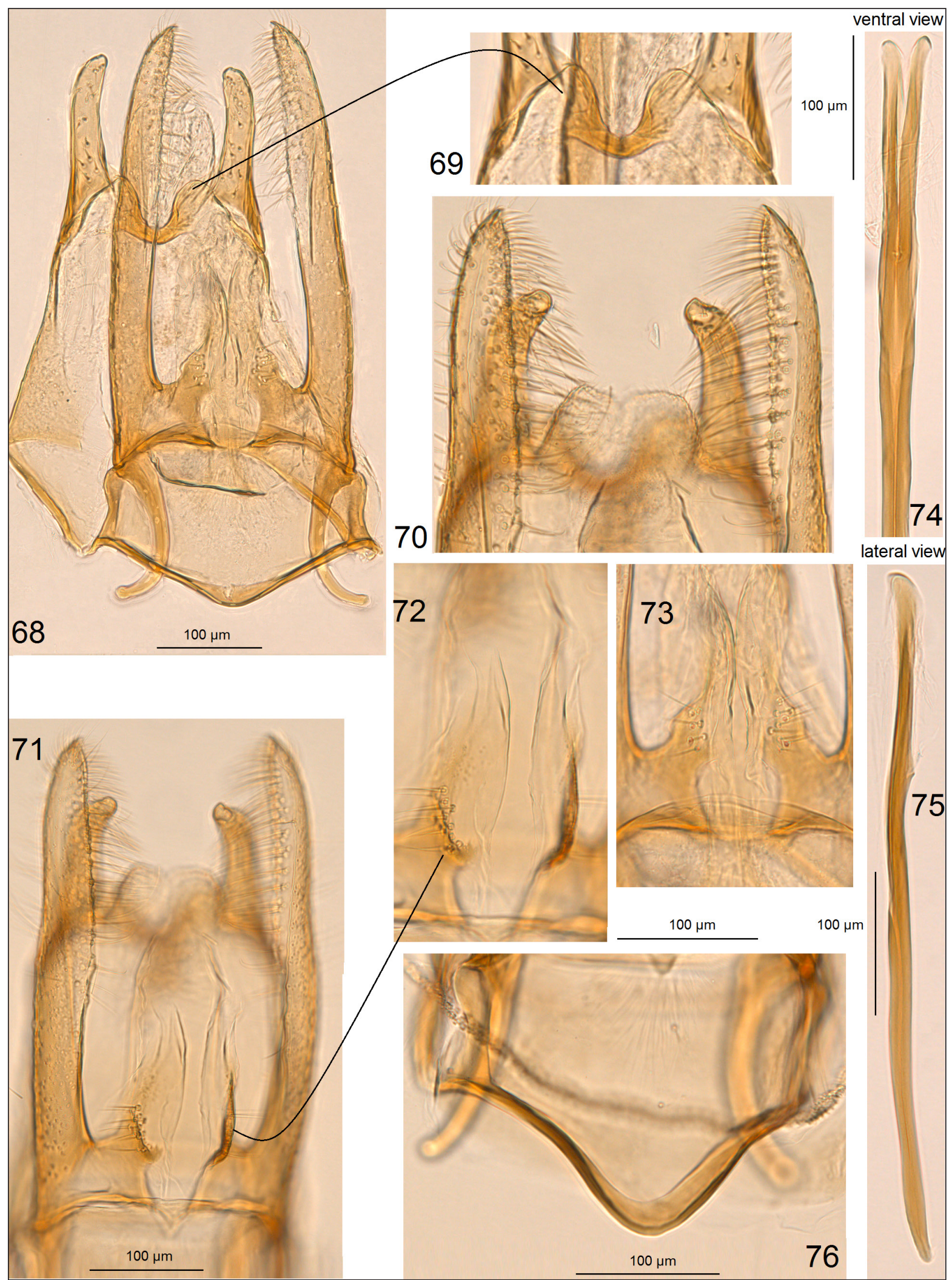

Figs 68-76. Male genitalia of Neotischeria longa Diškus \& Stonis, sp. nov.; 68, 69 - capsule with phallus removed, paratype, slide no. AD843 (ZIN); 70-71 - details of capsule, holotype, slide no. AD1082 (ZIN); 73 - same, paratype, slide no. AD843; 74 - phallus, holotype, slide no. AD1082; 75 - same, paratype, slide no. AD843; 76 - vinculum, holotype, slide no. AD1082 


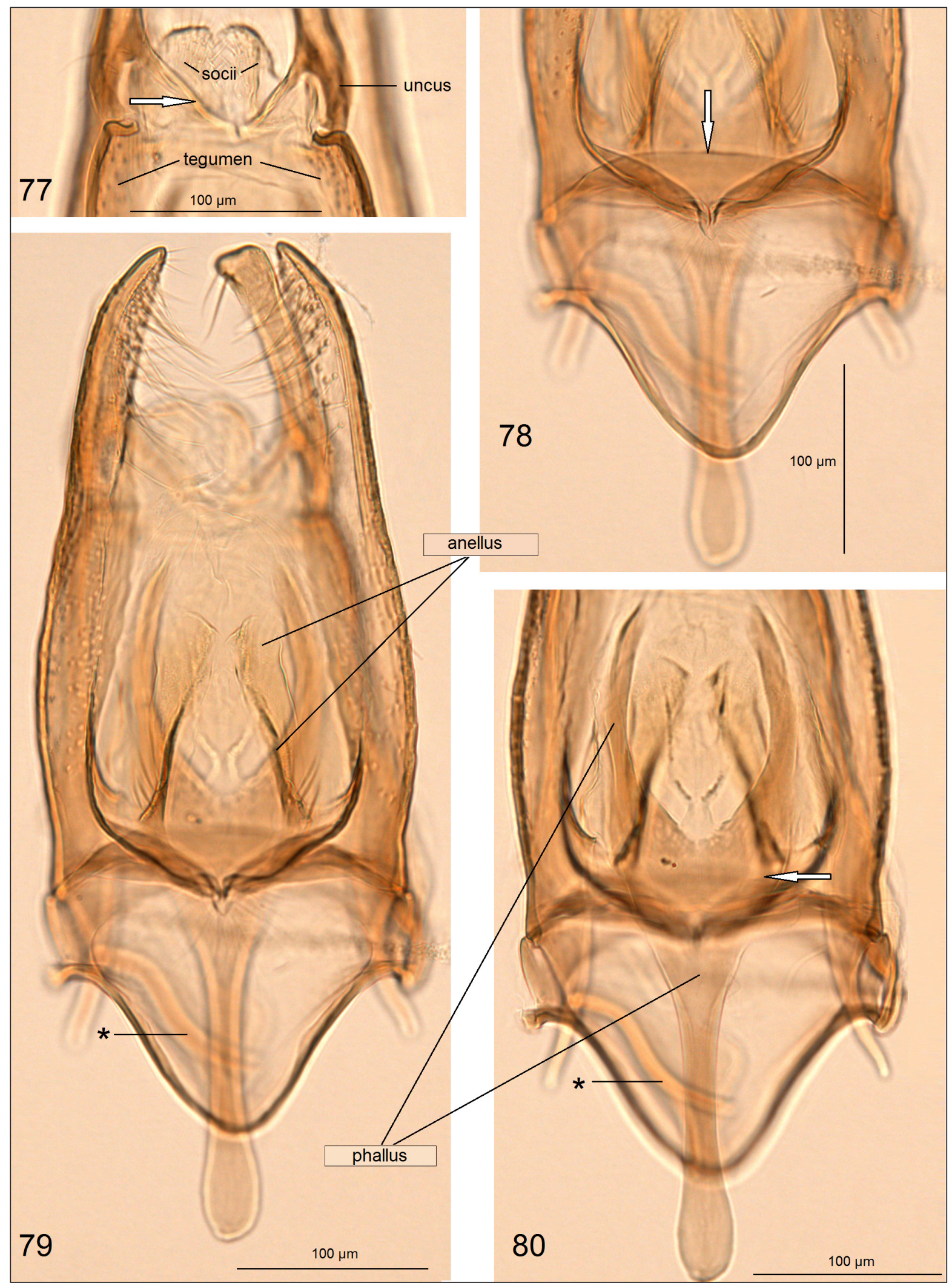

Figs 77-80. Male genitalia of Neotischeria poseidonia Diškus \& Stonis, sp. nov., capsule with phallus inside, holotype, genitalia slide no. AD1090 (ZIN). 77 - uncus and socii; 78 - vinculum; 79 - general view of capsule; 80 , same, focused on phallus 
Distribution. The species is known from tropical and subtropical western part of the equatorial Andes (Ecuador), at an elevation of about $810-2220 \mathrm{~m}$.

Etymology. The species name is derived from the Ancient Greek ochra (ochre colour) combined with the Latin pennatus (winged), in reference to the bright, ochre-yellow colour of the forewing.

Remarks. One female specimen with a label as the holotype (genitalia slide no. RA1089, NRC) was studied and photographed, but excluded from the type series. Because the dark scaling and small size of the specimen and our doubts about its belonging to $N$. ochripennata, this specimen was left unpublished here.

\section{Neotischeria longa Diškus \& Stonis, sp. nov.}

urn:1sid:zoobank.org:act:9FB2AC43-419741DD-9174-B92BD5D1385B

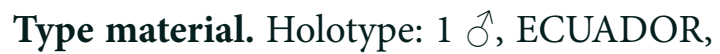
Chimborazo Province, $30 \mathrm{~km}$ NE Pallatanga, $1^{\circ} 52^{\prime} 41^{\prime \prime S}, 78^{\circ} 54^{\prime} 11^{\prime \prime} \mathrm{W}$, elevation ca. $3020 \mathrm{~m}$, from feeding larvae on Liabum sp., 21.ii.2007, field card no. 4877, leg. A. Diškus, J. R. Stonis, genitalia slide no. AD1082 $\hat{\jmath}$ (ZIN). Paratypes $(4 \hat{\jmath}, 4$ ㅇ): $3 \hat{\jmath}, 3$ ㅇ same label data as holotype, genitalia slides nos AD843 $\widehat{A}, \mathrm{AD} 1083 \propto$ (ZIN). Paratypes: $1 \hat{\delta}, 1$, same label data as holotype (NRC).

Diagnosis. From the most similar Neotischeria conexa sp. nov. (described above) it differs in the larger size of the adults and male genitalia. Additionally, from the central Andean N. conexa sp. nov., the equatorial Andean $N$. longa differs in the dark brown leaf mines (white in N. conexa); from the similar equatorial Andean N. ochripennata it differs in the blackish brown darkenings on male forewing (forewing ochre-yellow in N. ochripennata) and the slender phallus (basally widened in N. ochripennata).

Male (Fig. 43). Forewing length 3.7-5.0 mm; wingspan $8.0-10.8 \mathrm{~mm}(n=5)$.

Head. Frons, palpi, and pecten yellowish cream to pale ochreous yellow or pale ochre; frontal tuft pale brown basally, pale ochreous yellow distally; collar large, comprised of pale brown and brown, ochre-tipped scales; sometimes collar comprised of pale grey, cream tipped scales; antenna slightly longer than one half the length of forewing; flagellum pale greybrown, basally ochre cream; sensilla very fine but distinctive.

Thorax. Tegula grey-brown, distally pale ochre-brown. Thorax brownish cream to yellow cream. Forewing yellow-ochre, densely speckled with blackish brown scales in apical half; fringe mostly grey but apically pale yellowish ochre, with a fringe line of blackish brown scales; forewing underside grey-brown to dark grey-brown, with small scaleless spots and brown-black special scales along costa basally. No androconia. Hindwing dark grey on upper side, grey-brown on underside, without androconia; fringe pale grey, ochre glossy. Legs ochre cream, dark brown-grey on upper side.

Abdomen. Ochre-brown on upper side; paler, yellow-ochre, speckled with brown scales on underside; anal tufts dorsal, pale yellowochre; genital segments pale yellow-ochre. Genitalia (Figs 48, 68-76) with capsule about $610 \mu \mathrm{m}$ long (or $690 \mu \mathrm{m}$ long if measured from vinculum to valval tips), $280-290 \mu \mathrm{m}$ wide. Uncus comprised of two long latero-ventral lobes (Fig. 68) and two short, rounded dorsal lobes (Fig. 69). Valva (Fig. 71) about $460 \mu \mathrm{m}$ long (excluding the basal process), undivided, slender, basally fussed with anellus (Figs 68, 71). Anellus (Figs 72, 73) strongly thickened laterally, with two long, membranous lobes caudally. Vinculum triangular but rounded distally (Figs 68, 76). Phallus (Fig. 75) about $485 \mu \mathrm{m}$ long, slender, apically divided (Fig. 74), without lobes or spines.

Female (Fig. 44). Forewing length 4.0$5.4 \mathrm{~mm}$; wingspan $8.8-11.3 \mathrm{~mm}(n=4)$.

Thorax. Similar to male but forewing with bright yellow-ochre spots, thorax brown.

Abdomen. Bright yellow-ochre on underside. Genitalia (Figs 51, 52, 87-90) about $2110 \mu \mathrm{m}$ long. Ovipositor lobes (Figs 51, 88) very large, rounded, densely clothed with peg-like setae; area between ovipositor lobes moderately wide, 


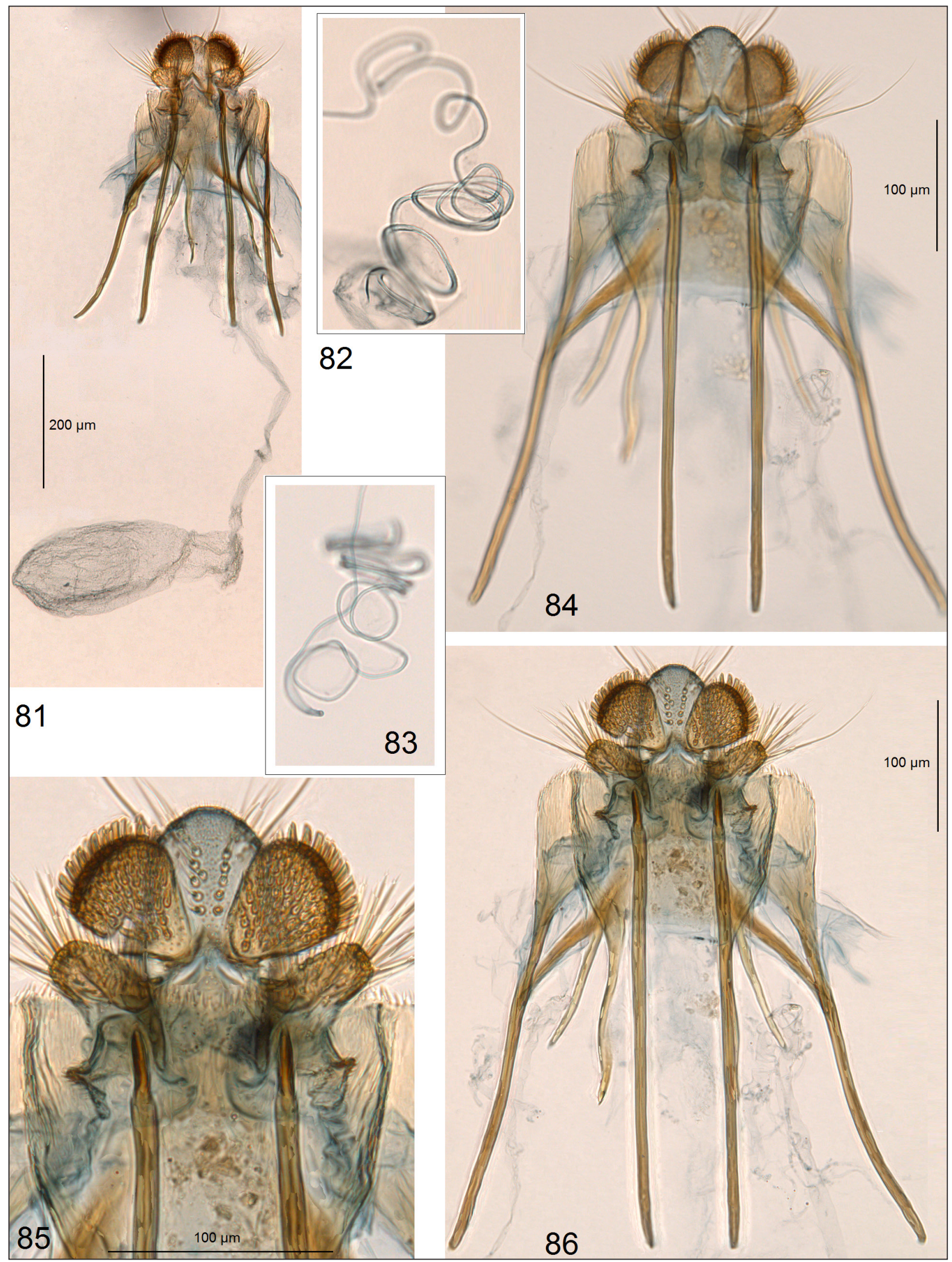

Figs 81-86. Female genitalia of Neotischeria conexa Diškus \& Stonis, sp. nov., paratypes. 81, 83 - genitalia slide no. AD1081 (ZIN); 82, 84-86 - genitalia slide no. AD1084 (ZIN) 


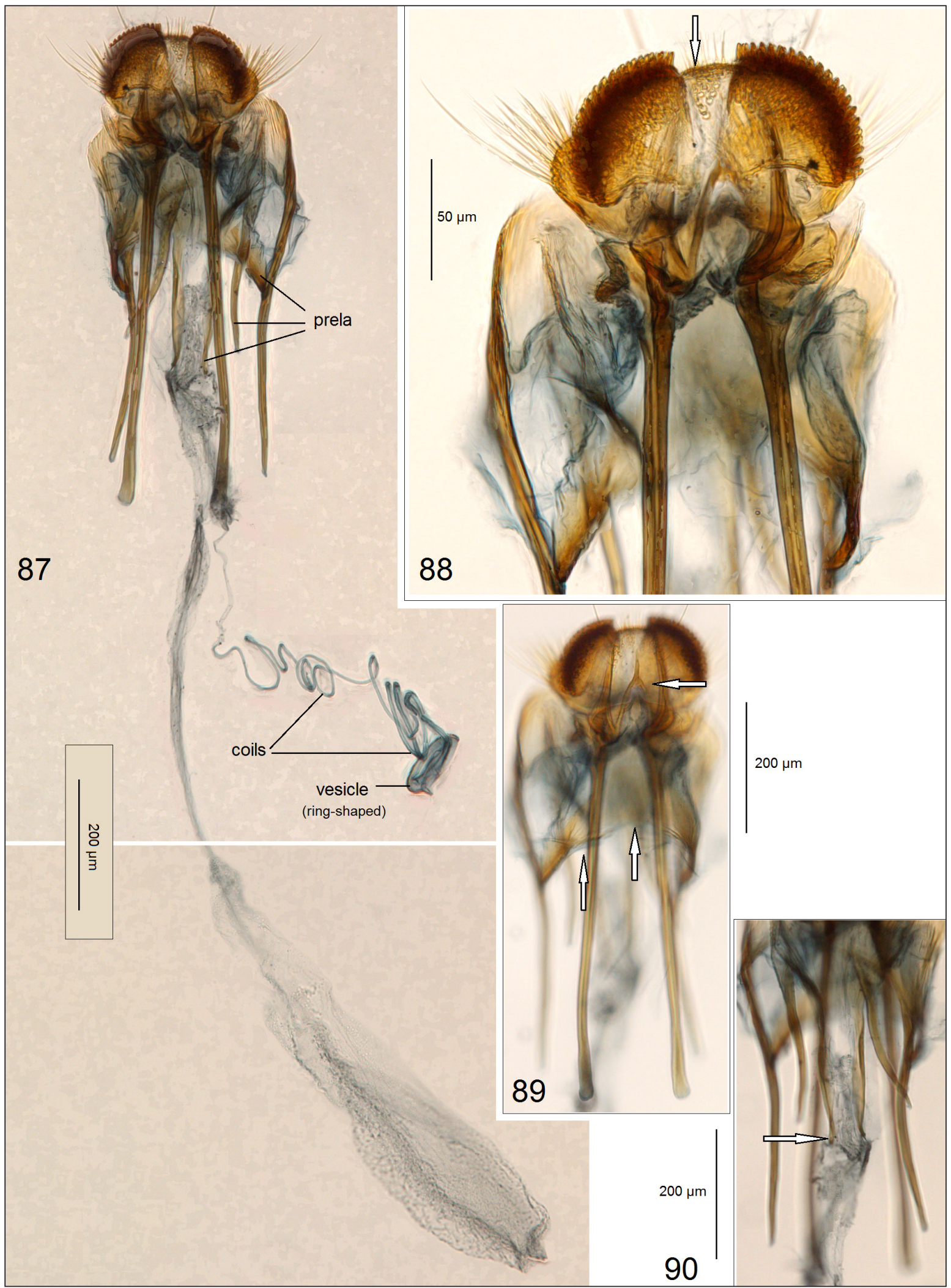

Figs 87-90 Female genitalia of Neotischeria longa Diškus \& Stonis, sp. nov., paratype, genitalia slide no. AD1083 (ZIN) 
with tiny papillae usually not collected in two rows (Fig. 51). Second pair of lobes, lateral and anterior to the ovipositor lobes, very small, indistinctive. Anterior apophyses slightly shorter than posterior ones; prela comprised of three pairs of rod-like projections (Figs 87, 89, 90). Corpus bursae (Fig. 87) very long and slender, basally wider, without pectinations or signum. Accessory sac absent or indistinctive. Ductus spermathecae very slender, with about 10 very large coils.

Bionomics (Figs 28-33). Host plant is $\mathrm{Li}$ abum sp., possibly L. dillonii D. G. Gutiérrez \& Katinas or L. igniarium (Humb. \& Bonpl.) Less., Asteraceae (Figs 28, 29). Larvae mine in leaves in February and produce dark brown, irregular blotch-like leaf mines (Figs 29-33). Pupation in a circular, indistinctive nidus inside the leaf mine. Adults fly in March. Otherwise, the biology is unknown.

Distribution. The species is known from the subtropical western part of the equatorial Andes (Ecuador), at an elevation of about $3020 \mathrm{~m}$.

Etymology. The species name is derived from the Latin longus (long), in reference to the very large size of the adults and their genitalia.

\section{Neotischeria guarani (Diškus \& Stonis, 2020) (comb. nov.)}

Paratischeria guarani Diškus \& Stonis, in Stonis et al., 2020b: 127-129, 142.

Host plant. Elephantopus mollis Kunth (Asteraceae).

Distribution. This species is known from the single locality in Paraguay, Departamento de Itapúa, Hohenau.

Remarks. Neotischeria guarani was illustrated by Stonis et al., 2020b: Figs 44-45 (adult), Figs 92-94 (male genitalia), Figs 95-97 (female genitalia).

\section{Neotischeria mesoamericana (Diškus \& Stonis, 2020) (comb. nov.)}

Paratischeria mesoamericana Diškus \& Stonis, in Stonis et al., 2020b: 129, 130-132, 134, 143, 144.
Host plant. Montanoa hibiscifolia Benth. (Asteraceae).

Distribution. Guatemala.

Remarks. Neotischeria mesoamericana was illustrated by Stonis et al., 2020b: fig. 46 (adult), Figs 98-104 (male genitalia), Figs 105-110 (female genitalia).

\section{Neotischeria belizensis (Remeikis \& Stonis, 2020) (comb. nov.)}

Paratischeria belizensis Remeikis \& Stonis, in Stonis et al., 2020a: 64-66.

Host plant. Unknown.

Distribution. This species is known from the single locality in Belize, Chiquibul Forest Reserve, Las Cuevas.

Remarks. Neotischeria belizensis was illustrated by Stonis et al., 2020a: Figs 24-25 (adult), Figs 124-127 (male genitalia).

\section{Neotischeria robinsoni (Diškus \& Stonis, 2020) (comb. nov.)}

Paratischeria robinsoni Diškus \& Stonis, in Stonis et al., 2020a: 55-59.

Host plant. Otopappus verbesinoides Benth. (Asteraceae).

Distribution. This species was described from Belize but recently five specimens ( $3 \hat{\delta}$, 2 O)have also been discovered in Guatemala (ZIN).

Remarks. Neotischeria robinsoni was illustrated by Stonis et al., 2020a: Figs 18-20 (adult), Figs 90-106 (male and female genitalia).

\section{Neotischeria tubifex (Diškus \& Stonis, 2020) (comb. nov.)}

Paratischeria tubifex Diškus \& Stonis, in Stonis et al., 2020a: 59-64.

Host plant. Lasianthaea fruticosa (L.) K. M. Becker (Asteraceae).

Distribution. This species is known from the single locality in Belize, Chiquibul Forest Reserve, Las Cuevas.

Remarks. Neotischeria tubifex was illustrated by Stonis et al., 2020a: Figs 21-23 (adult), 
Figs 107-117 (male genitalia), Figs 118-123 (female genitalia).

\section{The neotropicana group}

\section{Neoticheria neotropicana (Diškus \&} Stonis, 2015) (comb. nov.), a type species of the genus

Astroticheria neotropicana Diškus \& Stonis, 2015: 457-465.

Paraticheria neotropicana (Diškus \& Stonis), in Stonis et al., 2017: 14; 2020a: 66-68; 2020b: $135,147$.

Host plants. Sida rhombifolia L., S. spinose L., and S. acuta Burm.f. (Malvaceae).

Distribution. Paratischeria neotropicana is a tischeriid species with the broadest distribution range yet documented in the Neotropics, having been recorded from various localities in Belize, Mexico, Guatemala, Ecuador, Peru and Bolivia (Diškus, Stonis, 2015; Stonis et al., 2020b).

Remarks. Neotischeria neotropicana was illustrated by Diškus, Stonis, 2015: figs: 12-13 (adult), Figs 14-21 (male genitalia), Figs 22-27 (female genitalia).

\section{Neotischeria capnota (Meyrick, 1915) (comb. nov.)}

Tischeria capnota Meyrick, 1915: 247.

Paratischeria capnota (Meyrick, 1915),

Xu et al., 2017: 331.

Host plant is unknown.

Distribution: Peru (Lima).

Remarks. Male genitalia of the lectotype and paralectotype (deposited at the NHMUK) was studied and documented for the first time (see Figs 91-98).

\section{Neotischeria poseidonia Diškus \& Stonis, sp. nov.}

urn:lsid:zoobank.org:act:B128F35A-A76247A7-8457-5C2357C4ABDF

Type material. Holotype: $\widehat{\delta}$, GUATEMALA: Antigua Guatemala, San Juan del Obispo, $14^{\circ} 31^{\prime} 7^{\prime \prime} \mathrm{N}, 90^{\circ} 43^{\prime} 50^{\prime \prime} \mathrm{W}$, elevation ca. $1680 \mathrm{~m}$, from feeding larva, 25.ii.2012, field card no. 5113, A. Diškus, genitalia slide no. AD1090 ð’ (ZIN).

Diagnosis. Neotischeria poseidonia sp. nov. belongs to the $N$. neotropicana group. In the male genitalia, $N$. poseidonia from the most similar $N$. neotropicana and all other congeneric species differs in the strongly developed, broadly bifurcated and wide phallus (Fig. 80), caudally well-thickened vinculum (Fig. 78), and the distally membranous anellus (Fig. 79).

Male (Figs 45-47). Forewing length about $3.5 \mathrm{~mm}$; wingspan about $7.7 \mathrm{~mm}(n=1)$.

Head. Frons and palpi yellowish cream; frontal tuft comprised of lamellar scales, glossy yellowish cream; collar comprised of lamellar scales, yellowish cream with some pale grey scales; antenna only slightly longer than one half the length of forewing; flagellum glossy pale grey with some purple iridescence, basally yellowish cream; sensilla medium long, very fine, rather inconspicuous.

Thorax. Tegula speckled with dark grey scales, distally yellow-ochre; thorax yellowochre Forewing golden glossy, cream, densely speckled with pale yellow-ochre scales, with irregular pattern of black scales; fringe pale yellow-ochre, with a fringe line of black scales; forewing underside grey-brown, with brownblack scales along costa margin basally. No androconia. Hindwing and fringe brownish cream to pale grey depending on the angle of view. Legs golden cream, densely speckled with blackish grey scales on upper side.

Abdomen. Grey, with blue and purple iridescence on upper side; ochreous cream, distinctly annulated with dark grey-brown scales on underside; anal tufts dorsal, long, ochreous cream; genital segments ochreous cream. Genitalia (Figs 77-80) with capsule $470 \mu \mathrm{m}$ long, $200 \mu \mathrm{m}$ wide. Uncus (Figs 77, 79) comprised of two long and slender lateral lobes. Valva (Fig. 79) about $340 \mu \mathrm{m}$ long (excluding the basal process), slender, undivided, basally fused with anellus (Fig. 79). Anellus thickened only laterally, distally membranous, comprised of two indistinctive membranous lobes. Vinculum triangular but widely rounded distally 


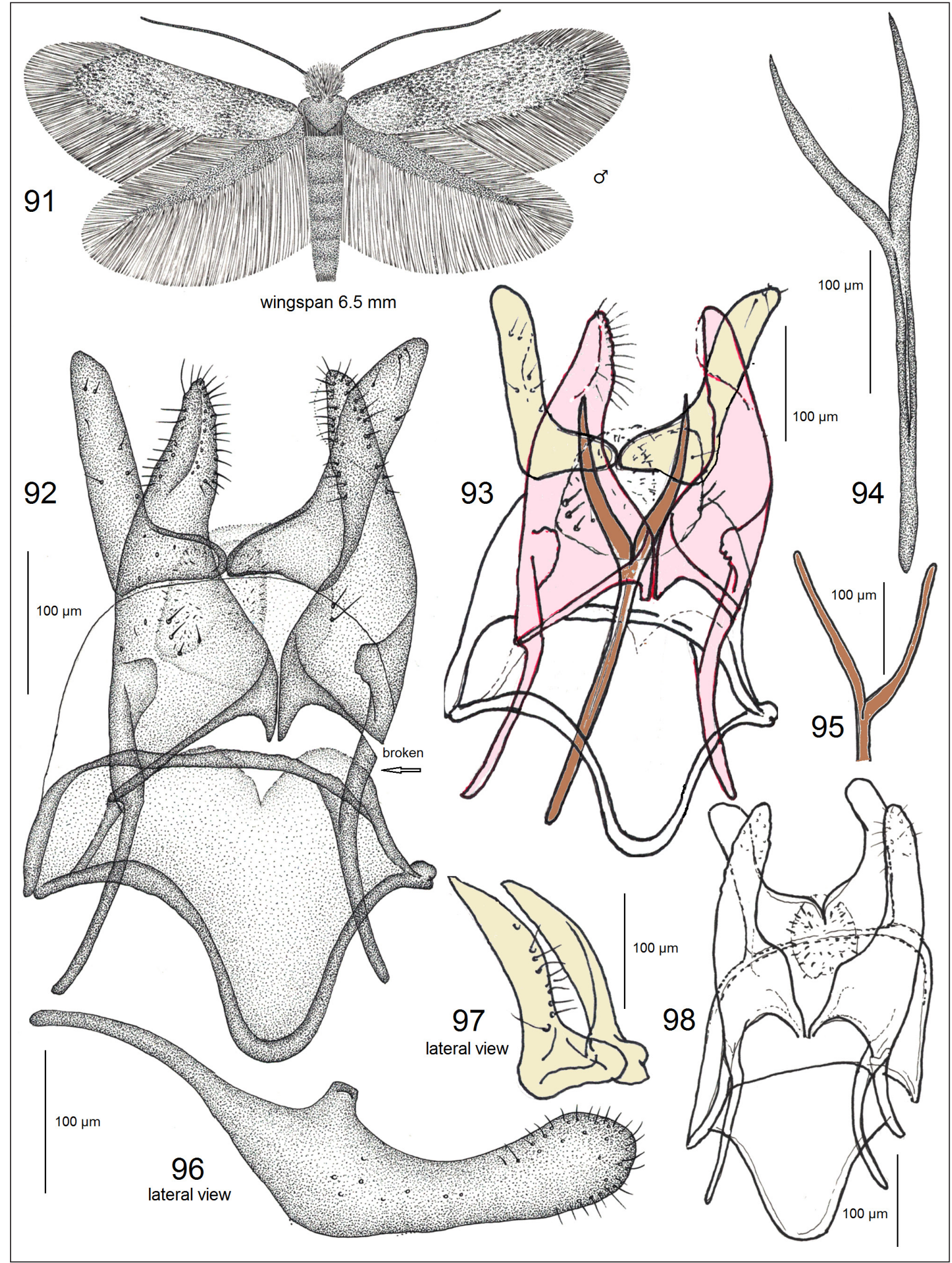

Figs 91-98. First documentation of Neotischeria capnota (Meyrick, 1915). 91 - male adult, reconstructed, after the lectotype and paralectotype (combined); 92 - lectotype, slide no. 28671, with phallus removed; 93 - same, with phallus inside; 94 - same, phallus; 95 - paralectotype, slide no. 29629, apex of phallus; 96, 97 - lectotype, lateral view of valva and uncus before permanent mount; 98 - paralectotype, slide no. 29629, capsule with phallus removed (NHMUK) 
(Figs 78, 79). Phallus $360 \mu \mathrm{m}$ long, very wide, robust, broadly bifurcated distally, without spines (Fig. 80).

Female. Unknown.

Bionomics. Host plant is unknown; it is expected to be a Malvaceae plant. Adults fly in March. Otherwise, the biology is unknown.

Distribution. The species is known from the single locality in Guatemala (Antigua Guatemala), at an elevation of about $1700 \mathrm{~m}$.

Etymology. The species name poseidonia (feminine, arbitrary created) is derived from Poseidon, one of the Twelve Olympians, a god of the sea, earthquakes, and horses in the Ancient Greek mythology, in reference to the colossal, fork-like phallus in the male genitalia of Neotischeria poseidonia sp. nov.

Note. Two other new Neotischeria species from Guatemala are already recognized but still undescribed (Stonis et al., in prep.). They do not belong to the neotropicana group.

\section{DISCUSSION}

The majority of the currently known $\mathrm{Ne}$ otischeria species, along with the majority of Astrotischeria, are trophically associated with Asteraceae, and only some utilize plants from Malvaceae. It is not known why Tischeriidae have been so successfully utilizing Asteraceae in the Americas (Stonis et al., 2020b). However, the estimation of the richness and taxonomic diversity of Asteraceae by Katinas et al. (2007) indicates that Central and South America are characterised by the globally highest generic diversity. Moreover, according to Barreda et al. (2010, 2012), the earliest fossils confidently assigned to Asteraceae suggest a South American-Antarctican origin of the Asteraceae family.

Recently it was shown that plants from Asteraceae are the most diverse hosts for many species of Stigmella Schrank, Nepticulidae in South America (Stonis et al., 2018b), and important host plants for other lepidopteran leaf miners (e.g. Vargas et al., 2012). It is surprising, but there are no Asteraceae-feeding Tischeriidae outside the Americas.
The new genus appears to be almost endemic to Central and South America (the Neotropical region) with a couple of species discovered further to the North: Arizona and California (USA). The Liabum host plants of the species described in this paper are characterised by a specific distribution from Central America to the central Andes (see Gutiérrez, Katinas, 2015) or, in the case of Smallanthus, to the Atlantic Coast of Brazil (see Vitali et al., 2015).

Two other species of this genus have been dissected, studied, and recognised, but not published yet (Stonis et al., in prep). We expect that this genus may comprise almost the double number of species compared with 13 provided in the checklist. Most likely, more species of Neotischeria will be discovered in future in the heavily undersampled Brazil and perhaps all other areas.

\section{ACKNOWLEDGEMENTS}

We are indebted to our Ecuadorian scientific partners, including those who participated in the initial project in 1999 by R. Puplesis and S. R. Hill, with Professor Giovanni Onore, a former professor at the Pontifical Catholic University of Ecuador, Quito, Ecuador. We thank Prof. Dr Jack Shuster (Universidad del Valle de Guatemala, Guatemala City, Guatemala) and the Consejo Nacional de Areas Protegidas (CONAP) Guatemala, C.A. for the Licencia de Collecta o Aprovechamiento de Vida Silvestre (No. 12900). Jonas R. Stonis thanks Julia Puplesyte-Chambers and the Environmental Programme at the Andes Office of NGO DAR Peru for permission to provide training courses and fieldwork within the project 'Rapid assessment of biodiversity plots of critical value in the provinces Chanchamayo and Satipo, Peru, and Bolivia, in cooperation with the BalticAmerican Biotaxonomy Institute in 2017-2018. We thank Prof. Dr Owen T. Lewis (University of Oxford, United Kingdom) for the material that he collected in 1997-1998 at Las Cuevas, a research station established jointly by the Forest Department of Belize and the Natural History Museum, London in 1994. 
For the help with the host plant identifications, we are also grateful to Dr Diego G. Gutiérrez (Museo Argentino de Ciencias Naturales), the author of the so useful monograph Systematics of Liabum Adanson (Asteraceae, Liabeae).

This research was partially funded by a grant (S-MIP-19-30, 'DiagnoStics') from the Research Council of Lithuania.

Received 23 June 2021

Accepted 12 July 2021

\section{References}

1. Barreda VD, Palazzesi L, Katinas L, Crisci JV, Tellería MC, Bremer K, Passalia MG, Bechis F, Corsolini R. An extinct Eocene taxon of the daisy family (Asteraceae): evolutionary, ecological, and biogeographical implications. Ann Bot. 2012; 109(1): 127-34. https://doi. org/10.1093/aob/mcr240

2. Barreda VD, Palazzesi L, Tellería MC, Katinas L, Crisci JV, Bremer K, Passalia MG, Corsolini R, Rodríguez Brizuela R, Bechis F. Eocene Patagonia fossils of the daisy family. Science. 2010; 329(5999): 1621. https://doi. org/10.1126/science.1193108

3. Braun AF. Tischeriidae of America North of Mexico (Microlepidoptera). Mem Am Entomol Soc. 1972; 28: 1-148.

4. Diškus A, Stonis JR. Astrotischeria neotropicana sp. nov. - a leaf-miner on Sida, Malvaceae, currently with the broadest distribution range in the Neotropics (Lepidoptera, Tischeriidae). Zootaxa. 2015; 4039(3): 456-66. https://doi. org/10.11646/zootaxa.4039.3.5

5. Gutiérrez DG, Katinas L. Systematics of Liabum Adanson (Asteraceae, Liabeae). Syst Bot Monogr. 2015; 97: 1-121. http://www.jstor. org/stable/24774226

6. Katinas L, Gutiérrez DG, Grossi MA, Crisci JV. Panorama de la familia Asteraceae (=Compositae) en la República Argentina. Bol Soc Argent Bot. 2007; 42(1/2): 113-29.
7. Kimura M. A simple method for estimating evolutionary rates of base substitutions through comparative studies of sequences. J Mol Evol. 1980; 16: 111-20. https://doi. org/10.1007/BF01731581

8. Kumar S, Stecher G, Tamura K. MEGA7: molecular evolutionary genetics analysis version 7.0 for bigger datasets. Mol Biol Evol. 2016; 33: 1870-74. https://doi.org/10.1093/molbev/ msw054

9. Meyrick E. Descriptions of South American Micro-Lepidoptera. Trans Entomol Soc Lond. 1915; 48(2): 201-56.

10. Puplesis R, Diškus A. The Nepticuloidea \& Tischerioidea (Lepidoptera) - a global review, with strategic regional revisions. Kaunas: Lutute Publishers; 2003. 512 p.

11. Stonis JR, Diškus A, Carvalho Filho F, Lewis OT. American Asteraceae-feeding Astrotischeria species with a highly modified, threelobed valva in the male genitalia (Lepidoptera, Tischeriidae). Zootaxa. 2018a; 4469(1): 1-69. https://doi.org/10.11646/zootaxa.4469.1.1

12. Stonis JR, Diškus A, Katinas L, Solis MA. Asteraceae: host to the greatest diversity of leafmining Nepticulidae (Lepidoptera) in South America? Proc Entomol Soc Wash. 2018b; 120(4): 856-902. https://doi. org/10.4289/0013-8797.120.4.856

13. Stonis JR, Diškus A, Monro AK, Dai X, Xu J. Most trumpet moths don't feed on plants of the nettle family but Paratischeria does: the first discovery of Tischeriidae (Lepidoptera) on Urticaceae in Asia. Zootaxa. 2021a; 5040(2): 247-264. https://doi.org/10.11646/ zootaxa.5040.2.5

14. Stonis JR, Diškus A, Paulavičiūtè B, Monro AK. Urticaceae-feeders from the family Tischeriidae: descriptions of two new species and new genus Paratischeria gen. nov. Biologija. 2017; 63(1): 1-22. https://doi.org/10.6001/ biologija.v63i1.3470

15. Stonis JR, Diškus A, Remeikis A, Katinas L, Cumbicus Torres N, Schuster J, PuplesyteChambers J. Diagnostics of new species of 
Neotropical Tischeriidae (Lepidoptera), with the first record of Coptotriche Walshingham from South America. Zootaxa. 2019a; 4691(1): 1-32. https://doi.org/10.11646/zootaxa.4691.1.1

16. Stonis JR, Diškus A, Remeikis A, Lewis OT. Exceptional diversity of Tischeriidae (Lepidoptera) from a single tropical forest site in Belize, Central America. Eur J Taxon. 2020a; 723: 3376. https://doi.org/10.5852/ejt.2020.723.1143

17. Stonis JR, Diškus A, Remeikis A, Navickaitè A. Study methods of Nepticulidae: micro-mounts of genitalia structures. In: Stonis JR, Hill SR, Diškus A, Auškalnis T, editors. Selected abstracts and papers of the First Baltic International Conference on Field Entomology and Faunistics. Vilnius: Edukologija Publishers; 2014. p. 32-5.

18. Stonis JR, Diškus A, Remeikis A, Solis MA, Katinas L. Exotic-looking Neotropical Tischeriidae (Lepidoptera) and their host plants. ZooKeys. 2020b; 970: 117-58. https://doi. org/10.3897/zookeys.970.54801

19. Stonis JR, Diškus A, Solis MA, Monro AK. Diagnostics of Manitischeria gen. nov., an Old-World genus of leaf-mining Tischeriidae, composed of new species and species formerly in Tischeria Zeller. Zootaxa. 2021b; 4964(2): 251-87. https://doi.org/10.11646/ zootaxa.4964.2.2

20. Stonis JR, Remeikis A, Diškus A, Davis DR, Solis MA. American Tischeriidae (Lepidoptera) from the collection of the National Museum of Natural History, Washington D.C. Proc Entomol Soc Wash. 2020c; 122(2): 482-505. https://doi.org/10.4289/0013-8797.122.2.482

21. Stonis JR, Remeikis A, Diškus A, Orlovskytè S, Vargas SA, Solis MA. A new leafmining pest of guava: Hesperolyra guajavifoliae sp. nov., with comments on the diagnostics of the endemic
Neotropical genus Hesperolyra van Nieukerken (Lepidoptera, Nepticulidae). ZooKeys. 2019b; 900: 87-110. https://doi.org/10.3897/ zookeys.900.46332

22. Stonis JR, Solis MA. Dishkeya gen. nov., a New World endemic genus of leaf-mining Tischeriidae (Lepidoptera), transferred from Tischeria Zeller. Biologija. 2020; 66(3): 123-35. https:// doi.org/10.6001/biologija.v66i3.4307

23. Vargas HA, Moreira G, Moreira RP. A new species of Bucculatrix Zeller (Lepidoptera: Bucculatricidae) associated with Baccharis salicifolia (Asteraceae) in northern Chile. Zootaxa. 2012; 3300: 20-33. http://www.mapress.com/ zootaxa/2012/f/zt03300p033.pdf

24. Vitali MS, Sancho G, Katinas L. A revision of Smallanthus (Asteraceae, Millerieae), the 'yacón' genus. Phytotaxa. 2015; 214(1): 1-84. https://doi.org/10.11646/phytotaxa.214.1.1

25. Walsingham TG. 1890. Steps towards a revision of Chambers's index, with notes and descriptions of new species. Insect life. 1890; 2(10): 322-26.

26. Xu J, Dai X, Liao C, Diškus A, Stonis JR. Discovery of Ulmaceae-feeding Tischeriidae (Lepidoptera, Tischerioidea), Tischeria ulmella sp. nov., and the first report of the Quercus-feeding T. naraensis Sato in China. Zootaxa. 2018; 4399(3): 361-70. https:// doi.org/10.11646/zootaxa.4399.3.6

27. Xu J, Dai X, Liu P, Bai H, Diškus A, Stonis JR. First report on Paratischeria from Asia (Lepidoptera: Tischeriidae). Zootaxa. 2017; 4350(2): 331-44. https://doi.org/10.11646/ zootaxa.4350.2.8

28. Zeller PC. 1839. Versuch einer naturgemässen Eintheilung der Schaben. Isis. 1839; 32(3): 167-224. 
Jonas Rimantas Stonis, Arūnas Diškus, Andrius Remeikis, Brigita Paulavičiūtè, Liliana Katinas, Nixon Cumbicus Torres

DIFERENCINĖ PARATISCHERIA IR NEO-

TISCHERIA GEN. NOV. DIAGNOSTIKA IR

NAUJOS, ASTERACEAE ŠEIMOS AUGALUS

MINUOJANČIOS, TISCHERIIDAE (LEPI-

DOPTERA) RŪŠYS IŠ CENTRINĖS BEI PIETŲ

AMERIKOS

Santrauka

Straipsnyje aprašoma nauja mokslui Neotischeria gentis ir keturios naujos rūšys; trys iš jų yra trofiškai susijusios su Liabum Adans. arba Smallanthus Mack. (Asteraceae) augalais: Neotischeria ochripennata Diškus \& Remeikis, sp. nov., N. conexa Diškus \& Stonis, sp. nov. ir N. longa Diškus \& Stonis, sp. nov. Šios rūšys yra paplitusios Andų kalnuose: Ekvadore, Peru ir Bolivijoje. Dar viena nauja rūšis - N. poseidonia Diškus \& Stonis, sp. nov. - buvo aptikta Gvatemaloje, tačiau jos mitybinis augalas iki šiol lieka nežinomas. Straipsnyje taip pat pateikiamas visų šiuo metu žinomų Neotischeria rūšių taksonominis sąvadas ir pirmą kartą dokumentuojamas iki šiol mažai žinomos rūšies - Neotischeria capnota (Meyrick) - lektotipas bei paralektotipas, kurie saugomi Londono gamtos muziejuje (Jungtinè Karalystè).

Raktažodžiai: lapų minos, minuotojai, mitybiniai augalai, nauja gentis, naujos rūšys, šeriuotaūsiai 